\title{
The Cytology of Laboulbenia chaetophora and L. Gyrinidarum.
}

\author{
BY \\ J. H. FAULL, B.A., Ph.D., \\ University of Toronto.
}

With Plates XXXVII-XL.

$\mathrm{T}$ HE Laboulbeniales possess many fundamentally important morphological features that cannot be properly interpreted until their underlying cytological phenomena have been elucidated. This is especially true of their organs of reproduction, including both gametangia and spore-sacs. Thus the latter have been rightly denominated asci by some botanists, but in the absence of any knowledge of their cytology - which recent investigations have shown to be essential to a definition of the ascus-others have advanced different views with regard to their nature, and correspondingly different speculations as to the taxonomic position of the group. By way of illustration it is needless to go farther afield than Engler's 'Syllabus ' ('07), in which they are classified as Laboulbeniomycetes, a class of equal rank with the Ascomycetes and the Basidiomycetes. The gametangia have played an even more prominent part in these speculations. This is particularly true of the female organ, whose striking resemblance to that of the red seaweeds has won for it the name of 'procarp', and given rise to the theory that the Ascomycetes are an offshoot of the Florideae with the Laboulbeniales as the connecting link. But every biologist nowadays realizes the unreliability of schemes of phylogeny, the sole capital of which is external morphology. The true homologies of the gametangia are quite as likely to be expressed by their cellular and nuclear phenomena. Hence, a knowledge of the latter is almost certainly needed before a satisfactory estimate can be made of any phylogenetic hypothesis based on the morphology of the organs of reproduction.

The sexual organs have also been of interest from another standpoint. Because they are well marked and apparently functional they have been cited as proof that the Ascomycetes have not parted with their sexuality. As a matter of fact, it has never been shown whether they are or are not sexually functional, or just how they may function-that remains to be determined by following patiently the fate of their nuclei. It is likewise 
noteworthy that, within the limits of the order, bisexual and unisexual species exist, and that, in connexion with the latter, heterospory and dimorphism have arisen, but concerning the associated cytological phenomena we know nothing. These and other matters provide abundant cause and stimulus for investigation. Since up to the present no contributions, apart from two brief articles by the writer (Faull, '05, '11), have been made on their cytology, several forms have been placed under investigation in the hope of discovering an answer to some of the problems that await solution. Some of the results obtained are presented here and some will be published in other memoirs. In this connexion, I wish to express my gratitude to Professor Roland Thaxter, who has most generously placed the rich stores of his intimate knowledge of this group at my disposal, and who has kindly examined some of my preparations and extended many other courtesies.

\section{MATERIAL AND METHODS.}

Laboulbenia chaetophora occurs on the edges of the elytra and the free tip of the abdomen of several species of the genus Gyrimus, the familiar 'whirligigs' common on ponds and along the quieter margins of streams and lakes. With it is frequently associated Laboulbenia Gyrinidarum, though in the two rather remotely separated regions from which the material for the investigations described in this paper was collected, the former species was abundant and the latter rare in one locality, while in the other the conditions were reversed.

$L$. chaetophora seems to prefer the free tip of the abdomen, on which it often grows in tufts of from two to ten or more individuals, and L. Gyrinidarum the margins of the elytra, which are not uncommonly fringed with a growth of the plants of this species.

$L$. chaetophora is the larger form of the two, sometimes attaining a length approximating a millimetre and a width one-fifth as great, a perithecium up to $400 \mu$ long, and a receptacle $52.5 \mu$ or more. The smaller form rarely reaches half a millimetre in entire length and $\mathrm{I} 60 \mu$ breadth. There are other well-marked distinctions, all of which are noted by Thaxter in the second volume of his monograph.

Of the available species of Laboulbenia, L. chaetophora presents the advantages of size, and mode and place of occurrence on the insect, though both lend themselves rather well to the manipulations about to be described. The material was collected in the neighbourhood of Guelph and Ottawa, Canada. While most of it was of the larger species, it was impracticable if not impossible to separate the species, and especially to distinguish the younger stages of the two forms from one another. However, they are so nearly alike and so closely allied that chances of error are practically negligible. 
The most serious difficulties in the way of technique, apart from those of obtaining suitable and adequate material, have been the securing of proper infitration of the reagents used, and the sectioning of the embedded portions of the host. The chitinous external wall of the fungus impedes the ingress of fixatives and often prevents it. Hot fixatives were sometimes employed, and in some instances gave excellent results, but by far the best were obtained by making an incision in each plant in the manner to be next described.

Preparatory to fixing, portions of the insect bearing the fungus were dissected off with scalpel or scissors, as little as possible of the integument of the insect being taken. Immediately after detaching such a piece, it was laid in a drop of the fixing fluid on a slide, and with the aid of a dissecting microscope and a pair of chisel-pointed needles the ends of the perithecia were snipped off. For this purpose needles with the finest points obtainable were mounted in match-stick handles and the points ground down to a sloping chisel edge. The material was then at once transferred to a phial filled with the fixing reagent. In the case of young plants the application of such technique was impracticable, and they were fixed without snipping, with the result that not infrequently fixation was not good. Snipped and unsnipped mature perithecia were sectioned by way of comparison. The former were invariably better preserved, the latter usually so badly as to be unusable. Several reagents were employed, but Flemming's weaker solution proved to be most satisfactory and was finally exclusively employed. As for stains, there is little to choose between Flemming's triple and Haidenhain's iron haematoxylin, the choice possibly resting with the former.

In order to overcome the obstacles offered in sectioning the host, some attempts were made at detaching the plants, usually during the embedding process, and handling them individually. With the larger subjects this can be done successfully, and by improving the methods possibly with all. But on account of their minuteness there is bound to be more or less loss in such a procedure, and as this is a serious consideration where material is none too abundant to begin with, this method was not very extensively employed.

By embedding in paraffin with a melting point of from $57^{\circ}$ to $60^{\circ} \mathrm{C}$., and cutting with a hard knife, sections from 3 to 5 microns can be obtained, though the chitin of the host almost invariably fractures before the knife. In order to soften this chitin, experiments were made by immersing the material in a solution of eau de Javelle after it had been hardened. This method was useless, however, because, while it dissolved the chitin, it also rendered the plants quite colourless and caused them to loosen from their points of attachment. 


\section{Cell-walls and General Envelope.}

The entire plant is enclosed by a thin, homogeneous, extremely tough, and impermeable continuous membrane or general envelope which is independent of the cells of the thallus. According to Thaxter it is the persistent gelatinous envelope which is first formed around the ripe spores just before they come to maturity and while still within the perithecium. Its impervious qualities are obviously of advantage, in that they protect the plant from the danger of desiccation.

This membrane is so thin that if embedded in hard paraffin it offers no serious resistance to the microtome knife. However, it very often checks or cracks and curls from the cut surface just as does a thin sheet of celluloid or hard rubber. It is often a serious hindrance to the fixing of sections to the slide, partly because it does not adhere well to glass, and because of its tendency to break and curl, thus disturbing the rest of the section during the various processes to which it is subjected in the course of staining and mounting.

The wall immediately underlying the general envelope is remarkably thick, and exhibits a curious differentiation, expressed both by structural peculiarities and characteristic reactions to staining media. Figs. 9 and 10 represent its morphological characters, from which it will be seen that it is laminated, and that the outer lamina is of different consistency and structure from the inner. The number of layers may vary, but usually from two to four or five can be counted.

The inner ones consist of a compact, non-granular substance, perfectly homogeneous and structureless, except for occasional radially arranged streaks, and with Flemming's triple or Haidenhain's iron haematoxylin take a light yellow stain or none at all. The streaks mentioned are darker in colour than the matrix in which they occur, since they vary from a smoky to a purplish tint. They have their bases or origin in the outer lamina, radiate more or less regularly inwards, at times branching, and frequently terminate at the inner boundary of a layer. Here they often expand into an irregular disc such as is illustrated in Pl. XXXVII, Fig. 9.

The outermost layer is of very different structure and staining capacity from the inner ones, and in the course of its development undergoes a very remarkable transformation. In the ripe spore nothing of peculiar interest is evident, but at an early stage in the history of the plantlet, after the walls have thickened, but while the substance of their component laminae is yet compact and non-granular, the peripheral layer soon shows its pronounced affinity for stains. The contrast to the inner layers is very marked, though not so much so as later, as at this stage the latter also show a tendency to take up stains. Later the contrast is sharp and complete, heightened so much the more by the circumstance that it adheres to the 
general envelope and often bears no apparent relationship to the protoplasts (Fig. 9). At a comparatively early stage the differentiation in structure referred to above becomes evident. At first it is little more than a mottling. The changes in structure, however, vary in different parts of the plant. In some regions there is a more or less uniform granulation of the lamella, in others the appearance of a radially arranged system of deeply stained rays grouped in plates. Reference to Figs. 9 and 14 will make clear what is meant. Viewed in section these plates look like dark, compactly striated bars of varying width, while viewed from the surface they resemble a honeycomb or net. With increasing age the plates disintegrate into granules, until finally the lighter areas, the meshes of the net, composed of the apparently almost unmodified wall substance, stand out as anticlinally oriented strands. In these changes it sometimes happens that one or more of the subjoined layers may become involved, but only secondarily so.

The strands which originate in this curious way are of very common occurrence in species of the genus Laboulbenia, and are of very characteristic appearance. Figs. IO and 12 represent the fully formed strands. By light reflected from their surfaces they appear quite black in stained preparations, but by transmitted light are light-coloured and bright, the latter quality being due to their comparatively high index of refraction. Fig. I I represents a portion of the general envelope that has been pulled away by the knife, and to which several of them are attached. The surface of such a portion of the plant viewed by transmitted light appears pitted or porous (Fig. I2). Indeed, Istvanffi ('95) described this punctate appearance, but interpreted the punctations as 'pore canals'. Thaxter rightly associated them with these strands or fibrillae, to the existence of which he was the first to call attention. Their formation, as has been seen above, is due to a more or less complete disintegration of the outer laminae, and in particular of the outermost. But as to the cause of this one can only conjecture. Instead of a granulation or degeneration of portions of the substance of the wall, as just described, in some instances there may be nothing more than a shredding, which is either an artifact or due to an unwonted stretching of an inelastic membrane. But shredding is exceptional, and cannot be offered as the cause of the origin of the ordinary type of fibril or the curious differentiation of the wall so early expressed in the life of the plant.

This account of the general envelope and external cell-walls does not apply to those of the trichogyne, the appendages, and the inner cells of the perithecium, all of which remain comparatively thin. Because of this fact the fixation of the appendages is usually good. In passing it may be pointed out that the appendages, in this species at least, appear to be capable of regeneration to a marked degree. New branches frequently spring from injured ones to replace the portions that may have been destroyed. The terminal cells in particular are long and thin walled, and are 
covered by a filmy colourless ' chitinous' envelope (PI. XXXVII, Fig. 2). It is noteworthy, too, that the protoplasm and nuclei of all the cells of the appendages, even in older plants, are apparently well nourished, and that they never show indications of decay. This is in contrast with the larger cells of the receptacle. The protoplasm in the latter often becomes very scanty and loosely reticulate, and the nuclei frequently have every appearance of being in a state of decadence, as is manifested by the fact that they sooner or later lose their sharp outlines, their contents show little or no structure, and sometimes an irregular, densely staining nucleolus accompanied by a greater or smaller mass of equally densely staining débris is all that remains of them. This disorganization is rarely, if at all, seen in the appendages.

The septa in the receptacle are resolvable into several layers, of which the middle lamella stains purplish and the others yellowish. The former is continuous with the darkly stainable layer in contact with the general envelope (Figs. 8 and 9). On it the others are superposed, the younger being less compact and more hyaline than the older. The septa separating daughters of the same mother-cell are single pitted (Fig. 7), so that there is a continuous protoplasmic tract from the base of the plant to the tips of the appendages.

The septa of the appendages are constructed like those of the receptacle, but are rather thicker than might be expected after what has been said of their peripheral walls (Fig. 1). Their pits, too, are surprisingly large. In L. chaetophora and L. Gyrinidarum the septa are black as seen from the edge, but sections and face views show that the blackening is superficial and mainly restricted to the portion of the general envelope covering the rim of the septum. The septum stains reddish for a short distance out from the pit, then there is a wider yellowish peripheral portion, and then the black rim (Fig. 2, a).

\section{PROTOPLASMIC BRIDGES.}

Possibly the most interesting features of the cell-walls are the pits and protoplasmic bridges. They are beautifully demonstrated and figured by Thaxter ('96) in Part I of his monograph, and it is strange that no reference is made to his descriptions by A. Meyer ('02), Kienitz-Gerlöff ('02), Strasburger ('01), and other botanists who have examined various Fungi to discover whether or not they possessed these structures.

De Bary ('84) appears to have been the first to note the existence of pits in the partition walls of the Fungi. He pointed out that they often possessed simple pits, and that those in Dactylium macrosporum were strikingly like those of the Florideae, such, for example, as in Callithamnion. The first work of any consequence on the subject of protoplasmic bridges in Fungi was done by Wahrlich ('92), who published an account of extensive 
investigations on a large range of forms. The extent of his observations may be judged from the fact that he drew his material from the following groups : Mucorini, Ustilagineae, Uredineae, Agaricineae, Polyporeae, Hynaceae, Tremeliineae, Clavariaceae, Hymenogastreae, Lycoperdaceae, Nidularieae, Saccharomycetes, Perisporiaceae, Hypocreaceae, Pezizeae, Helvellaceae, Tuberaceae, Parmeliaceae, and Cladoniaceae. In every instance Wahrlich found that the transverse septa were perforated by a single simple pore. In only one species, however, did he find protoplasmic bridges that closely resembled those of the Florideae, and of the Dactylium recorded by de Bary.

A. Meyer ('96) has also examined the Fungi from this standpoint quite independently of Wahrlich's publication, and later ('02) published an extended account of his researches on protoplasmic bridges and cell fusions in the Fungi, in which he fully corroborates the observations of Wahrlich. Baur ('98), Darbishire ('99), Woronin ('00), Strasburger ('01), and KienitzGerlöff ('02), and others have made more or less extensive examinations of the protoplasmic bridges in various Fungi and lichens, and all noted their existence.

It is aside from the purpose of this paper, however, to review the literature on this subject, except in so far as it touches the Laboulbeniaceae, the only account of which is given by Thaxter ('96). Concerning protoplasmic bridges in the Laboulbeniaceae, Thaxter offers the following: 'The protoplasm of adjacent cells, the origin of which is the same, is connected by a strand of the same substance, which passes from one cell to the other through a well-marked perforation of the cell-wall, the connexion being demonstrated with great ease by treatment with potash and subsequent staining (Pl. III, Figs. II-I2; Pl. II, Figs. I6-I8). In many instances, also, it may be seen in the living plant without the use of reagents. This protoplasmic connexion is found in all the cells, including those of the trichogyne, when this organ is multicellular. In many cases in which the cells had been separated by potash, and the connecting protoplasmic strand stretched between them, I have seen a slight enlargement like that indicated in Fig. I2, P1. III, recalling the similar structure through which the strands of protoplasm pass in the Florideae. I have, however, been as yet unable to determine its exact nature.'

Judging from microtome sections of the forms described in this paper, the thickening to which he refers may be the middle lamella, together with the granular accumulations to be found on both sides of it. The rather violent treatment of gross material with potash, followed by maceration, might very well tear out a portion of the middle lamella along with the strands. In this connexion Kienitz-Gerlöff's ('02) 'Neue Studien über Plasmodesmen' are of interest, as they deal with the bridges of the Florideae. $\mathrm{He}$ was able to verify the observations of Wahrlich and Meyer on 
the Fungi, but, surprisingly, was not able to satisfy himself as to the existence of uninterrupted protoplasmic bridges in the red seaweeds, a condition that seems so patent from a low-power examination of almost any filamentous member of the group. Indeed, he doubts the existence of bridges even in such a form as Polysiphonia: 'Gleichgültig, ob man die Pflanzen ohne oder nach mehrtägiger Behandlung mit $\mathrm{H}_{2} \mathrm{SO}_{4}$ oder $\mathrm{ZnClJ}$ untersucht, die beide so gut wie unwirksam sind, gleichguiltig ob man mit Jod, Methylviolett oder Hämatoxylin färbt, so findet sich in den meisten Fällen, auch an den günstigsten Objecten, wozu die Haare und einfädigen Zweige gehören, in den Tüpfeln zwischen den Zellen scheinbar eine deutliche Schliesshaut, welcher beiderseits eine halblinsenförmige, dunklere Protoplasmamasse angelagert ist, oder es liegt in den Verbindungen ein stark lichtbrechender Körper, über dessen Natur ich mir nicht ganz klar geworden bin. Mitunter gelang es mir freilich, ihn durch Behandlung mit Eau de Javelle zu entfernen, was für seine protoplasmatische Natur sprechen würde, aber diese Flüssigkeit löst allmählich die Zellen überhaupt aus ihrem Zusammenhange. Manchmal ist dieser Körper auch deutlich doppelt conturirt und linsenförmig. $\mathrm{Ab}$ und zu scheint freilich eine ganz homogene Verbindung zu bestehen, die so oft beobachtete Existenz jenes Körpers hat mich jedoch äusserst misstrauisch gemacht. Andererseits ist es auch möglich, dass die Erscheinung auf denselben Ursachen beruht, wie die so oft beobachtete Bildung des Knöpfchens in den Plasmodesmen der höheren Pflanzen.'

My observations on gross material, stained and unstained, coincide with those of Thaxter, but after an examination of hundreds of microtome sections of $L$. chaetophora I am driven to nearly the same conclusion as that reached by Kienitz-Gerlöff for the Florideae. ${ }^{1}$ The pits are easily found, and, as in the Florideae, never more than one in a septum; and so far as could be judged none of these is the result of fusions between cells such as Meyer has described in detail for other Fungi. But the middle lamella or 'Schliesshaut' stretches across the bottom of the pit, as shown in Pl. XXXVII, Figs. 7 and 20 , and there is considerable doubt as to the extent to which it is perforated. In a few instances, but very few, I have found a coarse strand of protoplasm, differing in no way from the cytoplasm of the protoplasts, passing from cell to cell, but these are undoubtedly exceptional phenomena.

The pits in the thin walls of young cells and of the inner sheath of perithecial cells are shallow and inconspicuous, but in thick septa are deep, always extending in as far as the middle lamella (Fig. 7). The cytoplasm dips into the pits, and, in the case of the deep ones, forms a coarse strand interrupted only by the middle lamella. The cytoplasm occupying

\footnotetext{
1 Connolly's observations on Rhabdonia globifera ('11) are not in accord with those of Falkenberg ('01) and Kienitz-Gerlöff ('02), for he reports a large strand of cytoplasm connecting contiguous protoplasts. His material appears to have been treated with strong solutions on the slide.
} 
the pit is usually clearer and more structureless than the rest of the cytoplasm. One of its most striking features, and one by means of which the position of the protoplasmic bridges can always be located, is the presence of rather coarse, deeply staining granules (a brilliant red with Flemming's triple stain), some of which are closely in contact with the 'Schliesshaut' (Fig. 7). These are probably the 'metachromatic' granules observed by Claussen in the mycelium of Ascodesmis and by McCubbin in Helvella.

In favourable preparations the middle lamella or 'Schliesshaut' can be seen to be perforated by a very fine pore, and in some instances there is the appearance of several minute perforations. But that there are no large openings to accommodate such strands as are obtained by the maceration of entire plants, or that permit of the uninterrupted continuity of the strands that occupy the pits, is absolutely certain. A possible exception is to be made in the case of the appendages, for as judged from end views of their septa, which are easily obtained in almost any section, each is occupied by a comparatively large open pore (Fig. I). Such an angle of observation is not favourable for the determination of the presence or otherwise of the thin middle lamella, but an occasional lateral view also gives the same impression. The black ring around the septum interferes seriously with observations from the side. The absence of the red granules characteristic of the bridges in the body of the plant lends further support to the possibility that the septa of the appendages are coarsely perforated, and that the protoplasmic bridges here are coarse strands of cytoplasm.

That there is a more or less definite organization of the cytoplasm related to the pitting of the septa is frequently evident, but will be referred to in another connexion.

\section{The Protoplast.}

The protoplasts are typically monoenergid, each cell possessing a single relatively large nucleus. Occasionally in older plants the nucleus in some of the cells may undergo one or more mitotic divisions. This may take place in the cells of the receptacle, especially in the larger ones, and in the cells lining the perithecium, but never in the foot, appendages, or spores. Fig. Ig illustrates an example of a large cell from the receptacle in which as many as ten nuclei were counted, all of uniform size and organization. Where such a proliferation occurs, the number varies from two to ten. Amitosis has not been seen in any instance.

The somatic nuclei are characterized by a large nucleolus and discrete masses of chromatin. There is no reason for believing that any portion of the chromatin is held by the nucleolus, for it is readily distinguishable in the resting nuclei in well-fixed preparations. The chromatin is especially abundant in the nuclei of the appendages. The nucleolus and chromatin 
stain bright red and the linin network blue. The chromatin is sometimes in shapeless masses, but most frequently in longer or shorter threads or granules (Fig. I). Whether or not there is a definite number I cannot say. Now and then only two chromatic elements can be counted; at other times four, while in other instances there seem to be more. Nor can I satisfy myself that they bear any relation to a central body, or, indeed, that a central body is a constant concomitant of the nucleus. It may be. Not seldom a granule that might be interpreted as such lies in contact with the nuclear membrane in the cells of the appendages, but as there are other red-staining granules in the cytoplasm it is difficult to say just what this particular one really is.

Mitotic figures in the hyphae of several Ascomycetes have been observed by a number of cytologists, excellent illustrations, for example, being given by Fraser ('08) for Humaria, and Schürhoff('07) for Penicillium. Faull ('05) and Dangeard ('07) have noted them in the spores.

The cytoplasm is finely granular or reticulate, but usually in the larger cells it is of a coarse spongy or reticulate structure. Oil bodies in L. chaetophora and L. Gyrinidarum are rare, but abundant quite highly refractive granular inclusions are of common occurrence. They may be small or quite large, and often regularly curved. Various sizes are shown in Figs. 36. They appear to be formed in the meshes or cavities of the protoplasm. The nature of these bodies was not determined. They make their appearance as the plant approaches maturity and do not show any especial affinity for the stains that were employed, though taking up the safranin and gentian violet to a limited extent, in contrast to the cytoplasm, which has a greater affinity for the orange G. Thaxter ('96) records an interesting fact in this connexion, namely, 'that the contents of the living cells consist of rather dense granular protoplasm, in which, as a rule, certain highly refractive spherical oily masses are conspicuous. In some instances these masses are few in number, one or more of them being often very large > (Pl. V, Figs. 4 and 5), while again they may be more numerous and uniform in size, completely filling the cells, as in the case of Laboulbenia Harpali, L. Philonthi, and many others.' Whether or not the bodies I have described are to be identified as the smaller ones detected by Thaxter I cannot say, but it seems not improbable that they are the same.

There is still another feature to be mentioned, to which reference has already been made, that is, the presence of protoplasmic strands running out from the pits in the septa and from the nuclei. These phenomena have been repeatedly observed. Fig. 20 illustrates a case in point. The strands passing out from a pit in one of the cells intersect those coming from the pit in the opposite septum. The strands are slightly darker, as if of denser substance than the rest of the cytoplasm, but at the points of intersection are several brightly red-staining granules, such as are to be found in the 
bottoms of the pits. In another cell the 'fibrils' are shown passing around the nucleus on their way across. It was thought at first that possibly these strands of cytoplasm connected the nuclei of contiguous cells in some way, such for instance as Strasburger found to be the case with pairs of nuclei in the same cell in Penicillium (Strasburger ('O2), Schürhoff ('07) contra), but Fig. 20 lends no support to such a view. It is true, nevertheless, that cytoplasmic fibrils can in some instances be traced from the pits to the nucleus, and that in degenerating cells they appear to be the most persistent parts of the cytoplasm.

That the nucleus bears a very evident relationship to the organization of the surrounding protoplasm at times has been dealt with in some detail by the writer in an earlier paper (Faull, '05). Hydnobolites and Sordaria furnish indubitable evidence of this contention.

\section{ANTHERIDIA.}

Careful and repeated search has been made for antheridia, but no organs resembling either the exogenous or the endogenous types have been discovered in either $L$. chaetophora or $L$. Gyrinidarum. So far as our knowledge goes these species afford examples of forms that have lost their antheridia. Belonging, as they do, to a genus characterized by conspicuous flask-shaped simple endogenous antheridia, it is not likely that they can have been overlooked, though that is not outside the range of possibilities. The cytology of both types of antheridia has been studied in other forms, and an account of the phenomena observed will be very shortly published.

\section{PROCARP.}

The procarp has its origin as a uninucleate terminal cell of a lateral branch of the receptacle (PI.XXXVIII, Fig. 2I). The two basal cells of the branch represented in Fig. $2 \mathrm{I}$ are daughters of the obliquely septated 'primordial cell of the perithecium', and give rise to the perithecium proper.

The course of development of the perithecium has been very carefully worked out by Thaxter, and so need not be recapitulated in detail here. It may be stated, however, that transverse sections wholly verify his statements that the number of rows in both the outer and inner walls is four, and that the rows of the two walls alternate with one another (Figs. 33-6). The inner is of later origin than the outer; in fact, does not appear until the latter is nearly complete and the procarp fully formed. Both are clearly outgrowths of the basal cells of the perithecium. They have been repeatedly seen in longitudinal sections in all stages of development, and their protoplasmic connexions with the basal cells demonstrated (Fig. 25). 
The mature procarp consists of three parts, the carpogonium, the trichophoric cell, and the trichogyne. The trichogyne is very highly developed in L. chaetophora and L. Gyrinidarum. It is an elaborately branched, frequently septated structure consisting of uninucleate cells (Figs. 30, 3I). It, too, has been figured and described by Thaxter, and little further can be added.

The possible functions of trichogynes that appear no longer to serve as receptive organs of spermatia have been recently fully discussed by Vuillemin ('07) and Brooks ('10), but so far as I know no experimental evidence has been adduced in confirmation of any of them.

The sequence of cell-formation in the carpogenic cell is strictly comparable to that described by Thaxter for L. elongata. The trichophoric cell undergoes no further division, though its nucleus as described below may play a very significant rôle. The carpogenic cell divides into three superposed cells, the superior and inferior supporting cells (s.s. and i.s.) and the ascogonium ( $a m$.) which lies between them. The ascogonium may again divide transversely, the lower half constituting a secondary supporting cell, while the upper usually divides by an oblique partition into the ascogenic cells (asc.) from which the asci (as.) bud out. In some plants this division does not take place, so that there may be but one ascogenic cell. Two, however, is the characteristic number, and never more than two have been found in the species here described. Two vertical rows of asci now bud out from each of the ascogenic cells. An account of their further development will be given in a subsequent section, and the cytology of the procarp only dealt with here.

The carpogenic cell is at first uninucleate, a relatively large nucleus with a large nucleolus occupying the centre of the cell (Fig. 22). The trichophoric cell is also uninucleate (Fig. 22). The single, centrally placed nucleus of the carpogenic cell now apparently divides; at all events it is succeeded by a pair of smaller nuclei (Fig. 24). I have not observed its actual division, but the nucleus represented in Fig. 23 appears to be in an early prophase stage. The nucleus of the trichophoric cell very soon moves down next to the carpogonium, as shown in Fig. 25, and undergoes a homotypic mitosis. The central bodies of the spindle are large and disc-like, but it is difficult to make sure of the number of chromosomes. At this stage, or even earlier, the partition separating the two cells disappears. Thus in Fig. 26 there is the appearance of a long single cell in which lie four nuclei, $\mathrm{A}, \mathrm{B}, \mathrm{C}, \mathrm{D}$, enumerating from the bottom up. A and $\mathrm{B}$ presumably are daughters of the carpogenic nucleus, $\mathrm{C}$ and $\mathrm{D}$ of the trichophoric. The lower end of this cell with nucleus $A$ is eventually cut off as the inferior supporting cell, and the upper end with $\mathrm{D}$ as a 'restored' trichophoric cell. But it was impossible to determine the exact sequence of septa-formation.

The middle pair, B and C, divide after a short period of growth, and 
their division is immediately followed by the separation of the superior supporting cell, which receives two of the four daughters, the other two remaining in what is now the ascogonium (Fig. 27). The two nuclei left in the ascogonium again divide, and a secondary inferior supporting cell is sometimes cut off which likewise appears to be characteristically binucleate (Fig. 28). The remnant of the ascogonium is still binucleate, and it may at once begin to bud off asci, or, as usually happens, first divide into two binucleate ascogenic cells (Fig. 28).

So far no nuclear fusions, nor any indications of such, have been observed.

By this time the perithecium has grown beyond the upper end of the receptacle, over which it curves as shown in Fig. 32. The supporting cells are still intact, but they are beginning to show signs of breaking down. This soon happens, and then the ascogenic cells with their asci come to lie free in the cavity of the perithecium, where they are sustained by the cells lining the perithecium. The latter are thin walled and well nourished. The upper cells lining the perithecium and the canal cells of the neck are crushed by the increasing mass of asci and spores soon after the perithecium has attained its maximum size, and eventually the same fate befalls those in the base of the venter.

A general survey of the Laboulbeniales reveals the fact that the procarp is characterized throughout by the constant occurrence of two cells, the carpogonium and the trichophoric cell. There is always a trichogyne, but it is extremely variable. The trichophoric cell is of especial interest since it is not represented in the Florideae or the Uredineae, and, if represented, is not determinable in any other Ascomycetes. Whether it is to be looked upon as a part of the trichogyne or as a part of a two-celled 'scolecite', its history and functions call for closer scrutiny. In the apogamous species investigated in this paper its nucleus joins forces with that of the carpogonium, a phenomenon quite comparable, without any thought of implying homology, to the initial stages of fertilization in certain Uredineae and possibly in such sac-fungi as Ascobolus.

Harper ('96) found that the cells of the scolecite of Ascobolus are primarily uninucleate, and that subsequently there is a migration of nuclei from cell to cell through perforations in the transverse septa of the scolecite. Welsford ('07) has fully corroborated his observations. Welsford states that 'the transverse walls of the scolecite are perforated medianly by large circular pores. Pores could not be identified in the earliest stages of development, and it seems possible that they may be of secondary formation. The nuclei with the cytoplasm of the several cells pass through the pores till they reach the ascogenous cell, where they fuse in pairs.' Though the history of individual migrating nuclei was not followed, the phenomena described are suggestive of what takes place in Laboulbenia chaetophora. 


\section{The Ascogenic Cells.}

The ascogenic cells are binucleate at all stages. The rather large nuclei divide simultaneously prior to the formation of each ascus (Fig. 37). This is a conjugate division: one of the daughters of each of the mother nuclei passes into the young ascus and the other remains in the ascogenic cell. The pair left in the ascogenic cell immediately begin to increase in size, and with the advent of the next ascus undergo another division. The divisions of the nuclei are homotypic, and, as has been seen to be the case elsewhere, the central bodies are conspicuous and the chromosomes four in number. In Fig. 39 a metaphase stage is represented in which the chromosomes are especially large and somewhat scattered, so that the count could be made with certainty.

The protoplasm of the ascogenic cells, as of the procarp, is dense and very finely granular, and exhibits a greater capacity for stain than the cells of the perithecium and receptacle, so that they always stand out clearly differentiated from the rest of the thallus.

The ascogenic cells of the Laboulbeniaceae have seemed to be unique among the Ascomycetes in respect to the limited and constant number for each species, and in respect to their capacity for giving origin to an unlimited number of asci. The number of ascogenic cells in Amorphomyces and two or three other genera is one, in Laboulbenia and several others two, in Stigmatomyces four; in Haplomyces there are eight, and in Polyascomyces there are thirty-two or more. This fixity of number is paralleled, however, by such genera as Sphaerotheca, in which there is a single ascogenic cell in every fruiting body, and as to the unlimited capacity of the ascogenic cells for ascus production I have found examples not at all uncommon in practically every order. The cytological details in these examples correspond to those in Laboulbenia in that a series of conjugate divisions takes place in the ascogenic cell in relation to a corresponding budding off of asci. Brefeld ('74) long since cited what has often appeared exceptional in the case of Penicillium, but theoretically at least his claims may be regarded as perfectly valid. The investigations of McCubbin ('10) and Brown ('10,'11) have shown the same thing expressed in another way for Helvella elastica, Leotia, and Lachnea, namely, that the nuclei of a potential ascogenic cell may undergo many conjugate divisions, and eventually give rise to many asci.

The common underlying principle is that of conjugate divisions, which is undoubtedly a character of the Ascomycetes. In Laboulbenia the apparatus involved is extremely simple, since the ascogenous cells correspond to the entire system of ascogenous hyphae and part of the female apparatus in most other groups. They are characterized by 
similar series of conjugate divisions, but undergo no considerable growth, no branching, and no septation.

\section{The Ascus.}

Thaxter was the first to discover that the spores of the Laboulbeniales are invariably borne in sacs, and constantly to the number of four, or in a few species of eight. On these grounds he has unequivocally maintained their ascigerous nature. It has only remained to examine the spore-sacs cytologically (Faull, '06, '11) to prove the correctness of his view, and to prove beyond question that they possess all the essential features of asci.

They begin as basipetally arranged folds or outgrowths of the ascogenous cells. They are never septated off from the latter, but their bases, which at first are very broad, gradually contract until finally the cytoplasmic connexion is broken. In Laboulbenia chaetophora the walls of the older asci are not always dissolved nor are the asci always completely sloughed off from the mother-cell (Pl. XXXIX, Fig. 4I), though both are common phenomena and are said by Thaxter to be characteristic for the group.

At first small, the ascus grows to a relatively large size, during which time the definitive nucleus also increases enormously in bulk. The cytoplasm is finely granular and fairly uniform throughout. When mature there is a slight vacuolation in both the upper and the lower parts of the ascus (Fig. 51), and sometimes a few insignificant granular inclusions make their appearance.

Two nuclei which we may with good reason assume to be lineal descendants of the pair that occupied the carpogonium in its later stages of development enter the young ascus and fuse with one another. Their chromatin is ordinarily distributed irregularly throughout the nuclear cavity in the form of a thread, an arrangement which persists for some time after fusion (Figs. 43-5). Eventually a synaptic contraction sets in (Fig. 46) and the threads are matted to one side of the nucleus, though their connexion with the nucleolus is probably maintained.

The synaptic stage is succeeded by one in which the threads are again loosely arranged, but this time much more regularly and with a more or less obvious relation to the nucleolus and an appearance of being paired. These features are clearly illustrated in Figs. 47 and 48. It will be seen, too, that there is a more or less regular system of achromatic threads radiating out from the nucleolus and traversing the entire nuclear cavity.

The next stage is characterized by a very marked diminution in the apparent amount of chromatin, and by what may possibly be interpreted as a second contraction. Figs. 49 and $49 a$ represent the same nucleus from two consecutive sections, and are designed to show the entire amount and 
disposition of the chromatin. It will be observed that the volume has diminished, and that the threads are thicker and more irregularly arranged.

Up to this time a central body has not been conspicuous, though probably present as indicated in Fig. 44. But now it can be found without great difficulty, and as shown in Fig. 50 the chromatin threads are apparently connected with it. Such a phenomenon was first discovered by Harper ('05) in Phyllactinia. It will again be noted that the polarity of the nucleus with respect to the nucleolus is still maintained, in which phenomenon the linin threads already described may play some part, since they appear to converge at the side opposite the nucleolus and there stand in connexion with the central body. This stage (Fig. 50) is immediately prior to the first mitosis, and constitutes a part of its prophase. The number of chromatic threads is clearly four, and these are identical with the four chromosomes to be seen on the spindle.

During all this time the nucleolus has been a very conspicuous organ. Each of the initial pair of nuclei contributed a large nucleolus, and these fused to form that of the definitive nucleus. Its growth throughout is steady and remarkable. In the later stages it becomes quite vacuolate and at times even somewhat honeycombed. During mitosis it steadily diminishes in size, but a portion of it still remains almost up to the time the daughter nuclei begin to form (Pls. XXXIX and XL, Figs. 42-54).

The first spindle is in many respects a very interesting structure. It is clearly intranuclear and is terminated at both ends by an extranuclear disc-shaped central body, evidently the products of division of the preexisting one already noted, from which stream out long astral rays. There are four elongated and curved chromosomes of unusual size for a fungus (Figs. $5^{\mathrm{I}-2}$ ). The achromatic portion of the spindle consists of two sets of fibrils, such as I have described in Hydnobolites, \&c. (Faull, '05) - a central system of many rather closely packed threads, and an outer mantle system. The mantle rays bear the chromosomes and appear to be responsible for their transport to the opposite ends of the spindle. After the chromosomes have reached the poles of the spindle the central fibrils experience a great elongation, carrying the daughter chromatic elements far apart (Pl. XL, Fig. 54). In some instances, not figured, the remains of this central spindle have been observed subsequent to the stage represented in Fig. 54, the fibres no longer separable, the whole thing resembling a coarse sharply defined dark cord, and irregularly wavy or crooked as though it had lost its former tension and was incapable of contraction. The daughter chromosome masses had probably moved slightly towards one another after the central spindle had fulfilled its function. This wide separation of the daughters of the definitive nucleus is a characteristic phenomenon of the first mitosis in every order of the sac-fungi. 
The chromosomes appear to divide transversely (Pl. XXXIX, Fig. 52) and, as they approach the poles of the spindle, show a tendency to split (Fig. 53). They are not homogeneous, for as seen in cross-section they do not stain uniformly. The centre may be hollow, at all events it is much lighter than the periphery. Fig. 53 presents some interesting features and is interpreted as follows: The chromosome at the extreme right is dividing transversely, the large one in the centre is still entire, the two pieces at the left are segments of the third chromosome, the uppermost is a daughter chromosome splitting, and portions of its sister, also longitudinally split, are on their way to the opposite pole.

The asters in the anaphase stage are even more distinct than earlier. A vacuole gradually forms around each of the chromosome masses, and the daughter nuclei very soon stand out clearly defined.

The second mitosis follows very swiftly on the heels of the first and is essentially different in many details. There is no preliminary synapsis stage, the spindle is sharper pointed, the central bodies are smaller, the chromosomes split longitudinally (Pl. XL, Fig. 55), the spindles are not differentiated as is the first, and there is no subsequent elongation. As a result of this the daughter nuclei lie side by side. Fig. 57 represents a tetranucleate stage of the ascus, showing the two pairs of sister nuclei.

The four nuclei now pass through a brief resting period, during which the chromatin is in the form of threads, and possibly in connexion with the persistent central bodies (Fig. 57).

During the prophase of the last mitosis the relation of the chromatin to the central bodies is more evident (Fig. 58). Presumably the latter divide, constituting the poles of the spindle on which four chromosomes, corresponding to the four threads of the prophase, take up a position in the equatorial plane (Fig. 59). It was not possible to determine just how the chromosomes divide, but they do divide, and there is no reduction in their number (Figs. 60, 6I). Nor was it possible to detect a differentiation in the spindle, which, whatever its constitution, is extensible, since the daughter nuclei are carried far apart (Fig. 62). The astral rays are long and tenuous. They are represented in Fig. 62 just before the spores are delimited, and again in Figs. $\sigma_{3}$ and $\sigma_{4}$ after this process is completed. That they do not fuse laterally and do not form a part of the limiting membrane is perfectly obvious, even were such a phenomenon as lateral fusion physically possible.

The spores are delimited progressively, beginning always at the central body. Relative to the process nothing more can be added than has already been described by the author and corroborated by Fraser and Brooks ('09) and Brown ('11), and in part by Dangeard ('07). Faull ('05): The spores are delimited 'by the differentiation of a limiting layer of hyaline or finely granular layer of protoplasm that begins adjacent to the 
centrosome and continues progressively until completed at the opposite pole.' Possibly there is a cleavage in this layer resulting in the plasma membrane of the spore and a corresponding membrane lining the cavity in which the spore lies. 'The astral rays never appear to fuse, as is stated by Harper to be the case in Erysiphe and Lachnea.' Fraser and Brooks ('09). These authors describe 'an outward flow of some substance which emanates from the centrosome' in Ascobolus and Lachnea. 'It has already been suggested', they add, 'that this substance is not improbably an enzyme.' This layer is the seat of a cleavage resulting in the two membranes mentioned above. 'We have, however, obtained no evidence of a lateral fusion of astral rays to form a membrane such as Harper describes, but we hold rather that the rays indicate rather the direction of flow of altered substance from the centrosome.' Berlese ('99) first suggested the possible directive action of the astral rays in laying down the limiting plasmatic spore membrane. 'Il cinoplasma determina poi la formazione dello strato parietale plasmatica dell' ascospora, ed individualizza quindi questa il sen al trofoplasma.' Dangeard ('07) could not differentiate the astral rays in his preparations of Pyronema, but he did detect a homogeneous sheet of material that issued from the central body and gradually delimited the spore. 'Il y aurait peut-être lieu de modifier légèrement la description classique donnée par Harper du mode de formation des ascospores dans l'asque et du rôle des filaments de l'aster; ici nous n'avons pas vu de filaments, mais seulement cette substance homogène chromatique qui enveloppe le noyau progressivement.' Brown ('11) affirms that the astral rays of Lachnea do not fuse to form the limiting membrane of the spore, and that they constitute no part of it. He also finds a membrane lining the cavity in the epiplasm in which the spore lies. Evidence from these independent sources indicates that Harper's interpretation of the part played by the astral rays of the last mitosis was incorrect. Moreover, from a physical standpoint Harper has affirmed an impossibility, as these long astral rays swinging down and out separate farther from one another (I refer to adjacent rays on the same side of the central body) rather than come into contact. Were they all laid side by side and welded into a ribbon they are so few and so tenuous that they would form a very small portion of the entire protoplasmic membrane of the spore. There is unanimity on one fact in this connexion described by Harper, namely, that the limiting membrane is formed progressively, but this feature is not more important than the determination of the origin of the membrane, as an exact knowledge of the latter must influence our conception of the homologies and phylogeny of the ascus itself.

After the spores are delimited in Laboulbenia, the flask-shaped nucleus continues to elongate until the neck is extremely attenuated (Fig. 64). In fact, the venter almost comes into contact with the opposite end of the young 
spore. The astral rays are observable up to this time, and in older stages lie much farther inward towards the nucleus and away from the limiting membrane than in the earlier stages, or for that matter in any other asci I have yet seen. They have been found here even more or less twisted about the attenuated neck of the nucleus (Fig. 64). These phenomena in themselves, even were lateral fusion of the longitudinal ribs of a globe physically possible, which is certainly not the case, are sufficient evidence that they do not fuse to form a protoplasmic membrane. The cavities in which the spores lie also appear to be lined by a protoplasmic membrane. The central body finally loosens its connexion at the older pole of the spore and takes up its position on the surface of the now spherical nucleus (Figs. 65 and 69$)$.

The long axes of the spindles of the third mitosis lie in the long axis of the ascus, consequently the asters are directed towards the upper and lower ends of the ascus respectively. Since there is no relative change of position during spore-delimitation it is possible to state with almost absolute certainty that the lower daughter nucleus of each spindle functions as a spore-former. That they lie approximately side by side in two pairs is merely a natural consequence of the disposition of the four nuclei of the second generation (Figs. 57 and 63 ). The upper daughter nuclei, on the other hand, initiate no spores, and pass at once to the upper end of the ascus (Fig. 65), where they eventually disintegrate.

\section{SPORES.}

From the first the spores lie with their long axes parallel to the long axis of the ascus. Almost spherical at the outset, they become broadly elliptical, then continuously more narrowly elliptical until their normal mature form is attained (Figs. 63-6). During the earlier stages of growth the nucleus remains at the upper or younger pole of the spore. At the same time chromatin is distinctly aggregated in proximity to the central body, simulating in a more or less striking manner the phenomenon of synapsis. Later the nucleus moves down well past the middle of the spore and there undergoes an ordinary homotypic mitosis, the chromosomes numbering four (Fig. 70). The spindle elongates somewhat and a thin septum is quickly formed between the daughter nuclei, dividing the spore into two cells. Whether or not a simple plate is formed progressively from the periphery of the spore inward I cannot say. Fibrils, possibly the spindle threads, may be seen passing from the nucleus to the young septum, and often a small plug lies at the centre of the plate, such as is represented in Fig. 67. Presumably there is a protoplasmic bridge, but only special refined methods would bring it out. The spore now completes its growth, and in addition to the ordinary wall, finally clothes itself with a gelatinous sheath which is 
strongly developed at the upper end, the future basal cell of the plantlet into which the spore will grow should it find favourable lodgement on a suitable host.

\section{Discussion.}

One immediate result of these investigations has been the confirmation of Professor Thaxter's classification of the Laboulbeniales as true Ascomycetes. This recognition is based on the characters of the spore sac, for the only positive diagnostic feature that distinguishes the Ascomycetes from other higher fungi is the ascus. That organ has been submitted to a very searching and successful examination during the past few years, so that our conceptions now concerning it when it is placed in comparison with the phycomycetous sporangium, the floridean tetrasporangium, or any other spore-bearing cell are no longer hazy. Every research has testified to the constancy of its nuclear heritage, and to the sureness with which certain characteristic cytological changes recur in the course of its development, all of which in combination suffice to distinguish it from every other sporebearing organ known in the organic kingdom. Thus the unfailing inheritance of a pair of nuclei, the regularity of their fusion in the young ascus, the minutiae of the successive three mitoses, and the details of spore-delimitation by a remarkable method of free cell-formation are uniform throughout the group and without a parallel in any other. Precisely the same phenomena characterize the spore sac of the Laboulbeniales, in fact so exceptionless as to throw no new light on the origin of the ascus. This faithful cytological similarity, therefore, affords conclusive proof that the Laboulbeniales can no longer be counted among the doubtful Ascomycetes, or that the Laboulbeniomycetes of the Engler system can be maintained as a class, or that they can rank other than as an order or suborder of the sac-fungi. Unquestionably, in accordance with prevailing definitions, the Laboulbeniales, Thaxter, are rightly regarded as Ascomycetes and as a suborder of the Pyrenomycetes.

Studies on the cytology of the Laboulbeniales have still another and very special interest in that they promise material additions to our knowledge of the sexuality of the Ascomycetes. This is a fascinating subject on its own account, and has also a wide bearing on the difficult problem of the phylogeny of the sac-fungi.

There is a strong tendency at the present time to regard the Ascomycetes in point of sexuality as unique among plants and animals, for it is commonly believed that their sexual phenomena comprise two successive nuclear fusions, one in the female gametangium or its substitute, and the other in the ascus. This, if true, would involve a quadrupling of the chromosomes in the fully fertilized egg and a subsequent double reduction. There is likewise a tendency to deny the existence of normal series of conjugate nuclear divisions in the Ascomycetes, though the subject has not 
been more than superficially investigated. Turning to the species described in this paper it will be seen that the observations noted do not bear out either of these views. The fusion of the nuclei in the young ascus is the only nuclear fusion found in the life cycle ; there is but one meiosis; and conjugate divisions play an important part.

Relative to the problem of the sexuality of the Ascomycetes it is becoming increasingly obvious that the phenomenon of conjugate divisions must be given serious consideration. The regularity of their occurrence among the Laboulbeniales is certain, and there is a growing body of evidence pointing to the generality of the phenomenon throughout all but one or two other subdivisions of the sac-fungi. That this feature has either been inherited from an earlier stock, or that it has been evolved within the Ascomycetes themselves, is self-evident. In either case, it would not be wholly unexpected to find occasional reversions to the more primitive procedure of a fusion of gamete nuclei directly following the conjugation of sexual cells. Such fusion nuclei would be potentially capable of at once forming spore-nuclei. It is understandable that sometimes, as Claussen asserts is true in Pyronema, there might be nothing more than pseudo-fusions in the gametangium, the actual fusions taking place normally in the asci. Such reversions would explain the recorded instances of fusion in the female gametangium, and the fallacy of assuming-what has never been demonstrated-that the sexual act comprises two successive nuclear fusions. The same tendency would also account for pseudo-fusions. In view of the need of research on the nature and extent of conjugate divisions in the Ascomycetes, especially because of the light an exact knowledge of this feature will throw on the problems of their sexuality and phylogeny, I venture to review the field and to explain the grounds taken above at greater length.

Cytological investigations on the higher Fungi in recent years have uncovered the interesting and universal phenomenon of a fusion of two nuclei in the spore mother-cell. An even more remarkable fact has been established for all but the Ascomycetes in this connexion, namely, that the fusing nuclei belong to two distinct lineal series the members of which have lived side by side in pairs, dividing conjointly without fusion for many generations.

Dangeard ('93), Sappin-Trouffy ('93 and '96), Blackman ('04), Christman ('05 and '07), Blackman and Fraser, ('06), and Olive ('08) have cleared the ground in the case of the Rusts. They have shown that a binucleate phase begins with the migration of a nucleus from one cell into another at a definite stage in the life-history, and that the progeny of these initial pairs accompany one another uncombined up to the teleutospores, where fusion ensues, followed at once by a reduction division. These events indicate that a curious type of sexuality has been evolved in the Rusts, one characterized by a long 
period of vegetative activity between the initial and the final phases of the sexual act.

Maire ('00-'02), Harper ('02), and Nichols ('04) have investigated a number of species of Autobasidiomycetes and have found that the cells of the lamellae of the Agaricaceae, and of the entire fruiting body and even part of the mycelium of some other forms, are binucleate, though so far no one has determined where or how this condition arises. Fruitful investigation is rendered difficult in most forms because the cells which might be expected to contain two nuclei are ordinarily multinucleate and the number of nuclei is not at all constant. Maire asserts the belief that where more than two occur in such cells the increased number is due to an amitotic multiplication of an original pair. The nuclear phenomena in the basidium have been studied by Wager ('93), Dangeard ('93), Maire ('02), and Fries ('11), and have been found to closely correspond to those in the teleutospore. Thus there is reason to believe that the same type of sexuality is expressed by the Autobasidiomycetes as by the Rusts.

The problems presented by the Ascomycetes have appeared at first sight less complicated in some respects than in the Basidiomycetes, owing to the existence among them of more or less conventional and in some instances apparently functional sexual organs, and the failure to recognize conjugate nuclei. A closer examination has revealed the fact, however, that a nuclear fusion takes place in the ascus just as it does in the basidium, and that the sexual organs exhibit a more perplexing multiplicity of forms than in any other group of plants. Several botanists have reported, too, that they have seen gamete nuclei fusing in the oogonium or its equivalent, and there is increasing evidence of the occurrence of characteristic conjugate nuclei. Indeed, the ensemble of facts has appeared so difficult of reconciliation that so far no view has been advanced that has not called into question the actuality of the existence of some one of them.

Harper ('96, '05), seconded by Blackman and Fraser ('06), Fraser ('08), and Claussen ('05), has contended that there are two successive nuclear fusions within the limits of a single life cycle, one in the female gametangium, the other in the ascus. They have actually seen both-at least, so they have interpreted what they have seen-but, granting the correctness of their interpretation, it is pertinent to insist that their claim that both occur in the same life cycle is a pure assumption. If their contention be correct, then, according to prevailing views regarding chromosomes in conjugating nuclei, there must be a quadrupling of the chromosomes with the second fusion, and in consequence a compensatory double reduction. Harper ('05) has consistently accepted this apparently inevitable theoretical deduction, and locates the site of the two reductions in the ascus. He considers that the double reduction is effected by the three mitoses in the ascus - an alluring hypothesis because of the obviousness of one meiosis and the universality of 
the three mitoses. Unfortunately-and here is the crux in this theory, the one direct proof that would establish beyond cavil the correctness of Harper's assumption of two nuclear fusions-he could find no indications of a second meiosis. The claim that there is such is merely the theoretical deducing of one assumption from another. Fraser ('08) and her co-workers, it is true, state that they have detected in certain forms indications of the theoretical second reduction, but Guilliermond ('11) has examined some of the same species and has seen nothing of them. Guilliermond, Dangeard, Maire, Brooks, the author, Claussen, as also Harper, have found no second reduction in the many forms examined by them, and the search has been by no means perfunctory.

Further, it may be added that though the generality of the occurrence of eight spores in the ascus is striking it is not exceptionless, and is no more remarkable and perhaps no more significant than the regularity with which the Laboulbeniales produce two-celled spores, or the Fucaceae eight-nucleated oogonia, or the Angiosperms eight-nucleated embryo-sacs.

While Harper's interpretations have received very general acceptance, there have been dissenters. Most notable among them is Dangeard, who has maintained on the strength of his own researches that the primary sexual organs, except in Eremascus and Dipodascus, are no longer functional, that they have been abandoned, so to speak, and that the sexual phenomena have been transferred to the ascus, in which the only nuclear fusion in the life cycle takes place. The gamete nuclei, he affirms, must then come from vegetative cells of the thallus, presumably from the peripheral cells of the ascogenous hyphae, and may travel together for one or more generations, dividing conjointly before fusing in the ascus. It seems strange that Dangeard has never observed a fusion of antheridium and oogonium in some of the forms studied by 'him, for example, Sphaerotheca, Erysiphe, and Pyronema, in view of the joint testimony of several seasoned botanists that such exist. Having failed to do so, however, he has unequivocally challenged the reliability of the observations of Harper, Claussen, et al., in respect to their assertion that they have observed these phenomena.

Maire ('05) has followed Dangeard's lead, and deems from what he has observed in Galactinia (cp. also Guilliermond ('05) on Acetabula leucomelas) that conjugate nuclei, or in his own terminology synkarions, are characteristic of the Ascomycetes, and hence that there is a more evident parallelism or homology throughout the Eumycetes than has been hitherto recognized.

Finally, Claussen ('07), after examining Pyronema, has burned his bridges behind him, and in a paper that bids fair to become a classic has championed an hypothesis similar to Maire's and Dangeard's, except that he locates the origin of the gamete nuclei that finally fuse in the ascus in the gametangia. He has observed migrations of nuclei from the antheridium into the oogonium and a pairing up of the nuclei in the latter, followed by 
what he takes to be conjugate divisions. What have been designated nuclear fusions in the oogonium he construes to be pseudo-fusions, for he finds a less intimate association between the pairing nuclei after they have entered the ascogenous hyphae. He is thoroughly satisfied in his own mind that all of the reported nuclear fusions in the gametangia (Harper ('96, '05), Claussen ('05), Fraser ('08), \&c.) have been misinterpretations of what were really pseudo-fusions - an explanation that lacks demonstration and hence open to some objections.

A perusal of the literature of the last decade or more on this subject cannot but occasion amazement at the enormous amount of energy expended in the effort to determine whether or not nuclei fuse in the female gametangium, and equally so at the meagre positive results that have been attained. Very probably some actual fusions have been observed, but the number is small, and if the theory of synkarions holds they may well be regarded as reversionary. On the other hand, the question of conjugate divisions has not been in the minds of most investigators, and so the subject has not been approached with anything like the same vigour from this angle. In spite of that, part of the ground in that direction has been cleared, and with promise that further effort will lead to a final solution.

The first step in this connexion has long since been taken, for it has been proved again and again that the nuclei fusing in the ascus are not sister nuclei, but that they are daughters of the mother nuclei that undergo a simultaneous division. In other words, they afford an instance of conjugate division recurring with unfailing certainty at a definite stage in the life cycle, and which every one admits. Maire ('05) and Guilliermond ('05) have likewise shown that both pairs of this division remain together in Galactinia and Acetabula, and that both are presumably capable of fusion. Some attempts to trace the ancestral lines of these nuclei farther back have been made, but as yet, with the exception of Claussen's studies on Pyronema, any certain knowledge is fragmentary. Massee ('05) has pointed out that binucleate cells are characteristic of thalli of various Ascomycetes. McCubbin ('10) in a much more definite manner has shown that in Helvella elastica there may be several conjugate divisions prior to fusion. Brown ('10, '11) reports the same features in Leotia and Lachnea. My own observations indicate that not only is this true of Helvella, but it is demonstrable for a number of forms belonging to the Exoascaceae, Helvellineae, Pezizineae, Plectascineae, and Pyrenomycetineae, including the Hypocreales, Sphaeriales, and Laboulbeniales. The repeated proliferation of hooks and the fusion of terminal and antepenultimate cells as observed by McCubbin, and almost simultaneously by Brown, is not an abnormality, as Carruthers ('11) would have it, but is an exceedingly common phenomenon in the Helvellineae and Pezizineae. Nor are conjugate nuclei restricted to the penultimate cells. Often, especially in the Plectascineae and Pyrenomycetineae, but also in some of the Disco- 
mycetes, they occur most abundantly in terminal cells, from which any number of asci may spring, or from other cells which may or may not be definitely located.

In view of these data I am thoroughly convinced that any investigations on the sexuality of the Ascomycetes and any phylogenetic scheme drawn up for the group must take cognizance of the phenomenon of conjugate nuclei or synkarions. It is admittedly manifest in the peripheral cells of the ascogenous hyphae throughout the class, except in a few forms that are marked by great simplicity. Indeed, it ranks here next in the regularity of its occurrence to the intricate phenomena in the ascus itself, and there is increasing evidence that the nuclear divisions in the ascogenous hyphae are of this type. Once having arisen, it is readily understandable how such a variation so favourable to increased sporogenous productivity from a single pair of gametes would persist and develop in one or several directions. The main difficulty arises in discovering just where the beginning was made. At some stage in the evolution of the group the principle must have been adopted. That is self-evident, for, regardless of differences of opinion as to its use, every one admits that this principle is utilized by all so-called typical sac-fungi. But where are these ancestors to be sought ?

Many have held that the Laboulbeniales are the living representatives of the first sac-fungi and that they had their beginnings in the red seaweeds. But this phenomenon of conjugate divisions only adds another specialization to the several of which no hint is given by the Florideae, and we know of no connecting links. It is true that our phylogenetic conceptions of the Ascomycetes are in such a plastic state that it is not inconceivable that delay in the fusion of gamete nuclei might have originated in some family of the Florideae, especially as there are good reasons for believing that this phenomenon has originated independently more than once in the Thallophyta But in the present state of our knowledge it would seem a more reasonable working hypothesis from many standpoints to look to the less specialized sac-fungi for the progenitors of the group. In them the gametes copulate and at once produce a single ascus. In Eremascus, for example, there is a fusion of the gamete nuclei followed by the immediate formation of an eight-spored ascus (Stoppel, ('07)). By a division of these nuclei before fusion two asci would have been possible, and by repeated divisions, several ; and by the elaboration of a system of synkarion carriers or ascogenous hyphae, an unlimited number.

It is, of course, to be borne in mind that, starting with the primitive forms, whatever they may have been, in which the phenomenon originated, several parallel lines have probably been worked out in which advantage of this method of multiplying the reproductive powers has been retained and elaborated. At the same time there would have been other changes of importance, such, for example, as an evolution of the sexual organs in more 
than one subgroup, resulting in heterogamous and apogamous conditions of varying complexity. In evidence, every one will admit that the sexual organs are among the most striking diagnostic features of such an assemblage as the Laboulbeniales. Simultaneously or otherwise, types of fruiting bodies would have been elaborated, especially with regard to protective and spore-disseminating adaptations. Obviously, whatever our conceptions of their race history may be, there will be agreement in believing that not one character alone but several have been involved in the evolution of the various subdivisions of the Ascomycetes, though there may be differences of opinion as to which, in certain instances, most importance is to be attached.

\section{SUMMARY.}

I. The cell-walls are laminated. The layer just below the general chitinous envelope is frequently differentiated into a fibrillar system by what appears to be a process of localized degeneration.

2. Single pits occupy septa separating cells of common origin. The protoplasmic bridges are typically very tenuous.

3. The protoplasts are monoenergid. In older cells the nucleus may repeatedly divide. Up to ten nuclei have been counted in a single cell of the receptacle.

4. No indications of antheridia in L. chaetophora or L. Gyrinidarum were found.

5. The procarp has its origin as a uninucleate terminal cell of a branch of the receptacle. The procarp consists of a uninucleate carpogonium, a uninucleate trichophoric cell, and a branched and septated trichogyne, each cell of which is monoenergid.

6. After the procarp is mature the carpogonium and trichophoric cell become continuous. Meanwhile the nucleus of the carpogonium is succeeded by two, which are apparently daughters of the carpogonial nucleus, and almost simultaneously the trichophoric nucleus undergoes division. Later a uninucleate trichophoric cell and a uninucleate inferior supporting cell are septated off from the now four-nucleated fusion cell. After further nuclear divisions a binucleate superior supporting cell and sometimes a binucleate inferior supporting cell are cut off. The binucleate ascogonium now begins to bud off asci or divides into two ascogenic cells, each of which contains a pair of nuclei. Up to this stage no nuclear fusions have been observed.

7. The nuclei of an ascogenic cell divide conjointly, a daughter of each passing into a young ascus. This process is repeated at the birth of every ascus. The pair entering the ascus soon fuse.

8. The fusion nucleus divides meiotically after a period of growth. The number of chromosomes is the same as in other mitoses. 
9. There are two other mitoses prior to spore formation, and both are homotypic.

IO. The spores are delimited by the method characteristic for ordinary sac-fungi. The astral rays do not fuse laterally to form the primary protoplasmic spore membrane.

II. Four only of the eight nuclei, the lower on each spindle, are functional in spore formation, the others soon degenerate.

I2. The main theoretical conclusions reached are as follows :-

(I) the Laboulbeniales are true Ascomycetes;

(2) it is probable that the only nuclear fusion in the life cycle takes place in the ascus;

(3) conjugate divisions of nuclei constitute a significant phase in the sexual phenomena of the sac-fungi.

UNIVERSITY OF TORONTO,

October 23, IgII.

\section{REFERENCES.}

Baur, E. ('98) : Zur Frage nach der Sexialität der Collemaceen. Ber. d. deutsch. bot. Ges., xvi. Berlese, A. N. ('99) : Studi citologici sui funghi. Riv. patol. veg., vii.

Blackman, V. H. ('04): On the Fertilization, Alternation of Generations, and General Cytology of the Iredineae. Ann. Bot., xviii.

Blackman and Fraser ('06): Further Studies on the Sexuality of the Uredineae. Ann. Bot., xx. gramulata. Proc. Roy. Soc., Ser. B., lxxvii.

Brefeld, O. ('74) : Botanische Untersuchungen über Schimmelpilze. Heft ii : Die Entwickelungsgeschichte von Penicillium.

Brooks, F. T. ('10): The Development of Gnomonia erythrostoma. Ann. Bot., xxiv.

Brown, W. H. ('09): Nuclear Phenomena in Py'ronema confuens. John Hopkins Univ. Cir., vi, $42-45$.

('10): The Development of the Ascocarp of Leotia. Bot. Gaz., 1, 443-459. ('11): The Development of the Ascocarp of Lachnea scutellata. Bot. Gaz., lii.

Carruthers, D. ('11): Contributions to the Cytology of Helvella crispa. Ann. of Bot., xxv.

Christman, A. H. ('05): Sexual Reproduction in the Rusts. Bot. Gaz., xxxix.

Rusts. Bot. Gaz., xliv.

Claussen, P. ('05): Zur Entwicklungsgeschichte der Ascomyceten Boudiera. Bot. Zeit., 1xiii.

('07) : Zur Kenntnis der Kernverhältnisse von Pyronema confluens (Vorläufige Mitteilung). Ber. d. dentsch. bot. Ges., xxv.

Connolly, C. J. ('11) : Beiträge zur Kenntnis einiger Florideen. Flora, ciii, Heft 2, I911.

DANGeard, P. A. ('93): Recherches sur la reproduction sexuelle des Champignons. Le Botaniste. Also a number of other articles in later volumes of Le Botaniste. ('94 -'95) : La reproduction sexuelle des Ascomycètes. Le Botaniste.

('95): La reproduction sexuelle chez les Basidiomycètes. Le Botaniste, $4^{\mathrm{e}}$ série. ('04-'07): Recherches sur le développement du périthèce chez les Ascomycètes.

Le Botaniste. 
Dangeard, P. A., et Sappin-Trouffy, P. ('93): Recherches histologiques sur les Urédinées. C. R. II6.

Darbishire, O. V. ('99): Über die Apothecienentwickelung der Flechte Physcia fulverulenta. Jahrb. f. wiss. Botanik, xxxiv.

DE BARY, A. ('84) : Vergleichende Morphologie und Biologie der Pilze, Leipzig.

Engler, A. ('07): Syllabus der Pflanzenfamilien, Berlin.

Falkenberg, P.: Die Rhodomelaceen des Golfs von Neapel und der angrenzenden Meeresabschnitte. Fauna und Flora des Golfs von Neapel und der angrenzenden Meeresabschnitte, xxvi, Berlin, I 901 .

Faull, J. H. ('05): Development of Ascus and Spore-formation in Ascomycetes. Proc. Bost. Soc. Nat. Hist., xxxii。

('06) : A Preliminary Note on Ascus and Spore-formation in the Laboulbeniaceae. Science, N. S., xxiii.

('11): Cytology of the Laboulbeniales. Ann. of Bot., xxv.

Fraser, H. C. I. ('08): Contributions to the Cytology of Humaria rutilans. Ann. Bot., xxii.

Fraser and Brooks ('n9): Further Studies on the Cytology of the Ascus. Ann. Bot., xxiii.

FrIES, R. E. ('11): Über die cytologischen Verhältnisse bei der Sporenbildung von Nidularia. Zeitschrift für Botanik, iii.

Guilliermond, A. ('05): Remarques sur la karyokinèse des Ascomycètes. Ann. Mycolog., iii.

Harper, R. A. ('96) : Über das Verhalten der Kerne bei der Fruchtentwickelung einiger Ascomyceten. Jahrb. f. wiss. Bot., xxix.

('02) : Binucleate Cells in certain Hymenomycetes. Bot. Gaz., xxxiii.

('05): Sexual Reproduction and the Organization of the Nucleus in certain Mildews. Carnegie Inst. of Wash., D.C.

IstvanfFI, Gy. DE ('95) : Eine auf Höhlen bewohnenden Käfern vorkommende neue Laboulbeniacee. Termeszetrajzi Fuzetek, xviii, Budapest.

Kienitz-Gerlöff ('02): Neue Studien uiber Plasmodesmen. Ber. d. dentsch. bot. Ges., xx.

Kniep, H. ('11): Úber das Auftreten von Basidien im einkernigen Mycel von Armillaria mellea. Dän. Zeitschrift für Botanik, iii.

KrüGer, F. ('10): Beitrag zur Kenntnis der Kernverhältnisse von Albugo candida und Peronospora Ficariae. Centralbl. fuir Bakt., Parasit. und Infektionskr., zweite Abt., xxvii.

Lawson, A. A. ('10): The Phase of the Nucleus known as Synapsis. Trans. Roy. Soc. Edin., xlvii, Part iii.

MAIRE, R. ('02): Recherches cytologiques et taxonomiques sur les Basidiomycètes. Annexe au Bull. de la Soc. Mycol. de France, Fasc. 4.

('05): Recherches cytologiques sur quelques Ascomycètes. Ann. Mycol., iii.

Massee, G. ('05): On the Presence of Binucleate Cells in the Ascomycetes. Ann. of Bot., xix.

McCubbin, W. A. ('10) : Development of the Helvellineae. I : Helvella elastica. Bot. Gaz., xlix.

Meyer, A. ('96): Das Vorkommen von Plasmaverbindungen bei den Pilzen. Ber. d. deutsch. bot. Ges., xiv.

('02): Die Plasmaverbindungen und die Fusionen der Pilze der Florideenreihe. Botanische Zeitung, lx.

Nichols, S. P. ('04): The Nature and Origin of the Binucleated Cells in some Basidiomycetes. Trans. Wisc. Acad. of Sci., \&c., xv.

Olıve, E. W. ('08): Sexual Cell Fusions and Vegetative Nuclear Divisions in the Rusts. Ann. of Bot., xxii.

Sappin-Trouffy, P. ('96): Recherches histologiques sur la famille des Urédinées. Le Botaniste, v. Schürhoff, P. ('07) : Über Penicillium crustaceum. Beih. Bot. Centralbl., xxii.

Stoppel, R. ('07): Eremascus fertilis n. s. Flora, xcvii, Heft 3.

Strasburger, E. ('01): Über Plasmaverbindungen pflanzlicher Zellen. Jahrb. für wiss. Bot., xxxiii. ('02): Das Botanische Praktikum. 4. Aufl.

Thaxter, R. ('96) : Contributions towards a Monograph of the Laboulbeniaceae, Part I. Mem. Americ. Acad. of Arts and Sci.

('08): Contributions towards a Monograph of the Laboulbeniaceae, Part II. Mem. Americ. Acad. of Arts and Sci.

Vuillemin, P. ('07): Les bases actuelles de la systématique en mycologie. Progressus Rei Bot., zweiter Band. 
Wager, H. ('93): On Nuclear Division in the Hymenomycetes. Ann. Bot., vii.

Wahrlich, M. ('92) : Zur Anatomie der Zelle bei Pilzen und Fadenalgen. St. Petersburg. (Russian.)

Welsford, E. J. ('07): Fertilization in Ascobolus furfuraceus, Pers. The New Phytologist, vi.

Woronin, M. ('00): UUber Sclerotinia cinerea und Sclerotinia fructigena. Mémoires de l'Académie Impériale des Sciences de Saint-Pétersbourg, Classe physico-mathématique, $\mathrm{x}$, No. 5 .

\title{
DESCRIPTION OF FIGURES IN PLATES XXXVII-XL.
}

\author{
Illustrating Professor Faull's paper on the Cytology of Laboulbenia.
}

\section{PLATE XXXVII.}

Fig. I. Part of appendages of a mature plant of Laboulbenia chaetophora. All of the septa except the two uppermost are represented in section. The two in black illustrate the septa as they ordinarily appear, because of the fact that the wall at the periphery of the septum is opaque black in nature and so obscures the inner details. $\times 2,700$.

Fig. 2. The apical cell of an appendage. $\times 2,700$.

Fig. $2 a$. An ordinary septum from an appendage as seen in face view. The black line represents the peripheral black chitinous wall substance, and the opening in the centre the single 'pore' or ' $p$ it'. $\times 2,700$.

Figs. 3-6. Portions of cells from various parts of the main body of the mature plant, showing the structure of the protoplasm with granular inclusions as it appears in sections. Fig. 3 is from one of the lower and larger cells. $\times 2,000$.

Fig. 7. The ordinary type of pit in the main body of plant. Hyaline cytoplasm and intensely staining granules occupy the depressions. The middle lamella is very finely perforated, if at all. $\times \mathrm{I}, 350$.

Fig. 8. A very exceptional instance of a wide open pore from the lower part of receptacle. $\times \mathrm{I}, 35^{\circ}$.

Fig. 9. A section of outer wall of a young plant, showing the chitinous covering, the fibrous layer in course of differentiation (the unstippled bars are the unchanged wall substance that later constitutes the fibrils), and the inner laminae streaked here and there by fine dark threads. $\quad \times 2,700$.

Fig. 10. A later stage, showing the fibrils. $\times 2,700$.

Fig. II. A part of the chitin torn away by the knife and to which several fibrils are attached. $\times 2,700$.

Fig. 12. A bit of the outer wall, comprising the chitinous covering and the fibrous layer, shown in three dimensions. The porous appearance of the chitinous covering is due to underlying transparent fibrils. $\times 2,700$.

Fig. I3. The surface of the fibrous layer immediately in contact with the chitin. $\times 1,800$.

Fig. I4. A bit of the fibrous layer in an early stage of differentiation shown in three dimensions. The portions not stippled are unmodified parts of the layer which later give rise to the fibrils. $\times 1,800$.

Fig. I5. From uninucleate stage of spore; the nucleus in division. $\times 2,700$.

Figs. 16-18. Stages immediately following Fig. 15. In Fig. I8 the septum is complete. $\times 2,700$.

Fig. 19. A multinucleate cell from the receptacle of a mature and probably old plant. $\times 900$.

Fig. 20. A portion of thallus, showing pits in walls and cytoplasmic fibrils. $\times 1,800$.

\section{PLATE XXXVIII.}

Fig. 2I. Part of young thallus. Uppermost cell is the initial of the procarp. The cells just below give rise to wall of perithecium. $\times 600$.

Fig. 22. Section through a young plant. The outer wall of perithecium is complete; one cell 
of the inner wall, which is just beginning to form, is shown at the left. The carpogonium and trichophoric cell of the procarp occupy the axis of the perithecium. $\times 600$.

Fig. 23. A slightly older stage. The inner wall of perithecium is now well on the way. $\quad \times 600$.

Fig. 24. A still older stage, although the inner wall of perithecium is not as far developed as in Fig. 23. The nucleus of the carpogonium appears to have divided into two, and the septum between the carpogonium and trichophoric cell is no longer visible. $\times \mathrm{I}, 350$.

Fig. 25. A later stage, in which the trichophoric nucleus is seen in the act of dividing. $\times 600$.

Fig. 26. A later stage. $\times 600$.

Fig. 27. An older procarp. The cells in order from the top down are, trichophoric cell, superior supporting cell, carpogonium, and inferior supporting cell. $\times 45^{\circ}$.

Fig. 28. From the bottom up are the inferior supporting cell, secondary inferior supporting cell, ascogenic cells, superior supporting cell, and trichophoric cell. (Drawn from two sections.) $\times 600$.

Fig. 29. In the axis are to be seen an ascogenic cell, secondary inferior supporting cell, and the remains of inferior supporting cell. $\times 600$.

Fig. 30. Upper end of a young procarp, at the stage represented in Fig. 22, showing trichophoric cell and trichogyne. $\times 450$.

Fig. 31. A combination of Figs. 22 and 30 , with the trichogyne restored from other sections of same series, and hence in part conventional. $\times 450$.

Fig. 32. An older stage than in Fig. 28. The young asci have begun to grow out. In the axis, from the upper part down, are the trichophoric cell, superior supporting cell, two asci, two ascogenic cells, secondary inferior supporting cell, and inferior supporting cell. Partly conventional. $\times 600$.

Figs. 33-6 are transverse views of the same young fruiting organ taken at successively lower levels, and designed to show the position of the procarp and the relation of the two perithecial walls to one another. $\times 45^{\circ}$.

Fig. 37. An ascogenic cell in which the nuclei are dividing, and an ascus in which the nuclei have not yet fused. $\quad \times 2,700$.

Fig. 38. An ascogenic cell and four of its asci. $\times 1,800$.

Fig. 39. Nucleus of a spore in metaphase stage. $\times 2,700$.

Fig. 40. Photograph of anal plate of host with two attached Laboulbenia chaetophora.

\section{PLATE XXXIX.}

Fig. 4I. Two ascogenous cells with asci, as seen in a single section. The collapsed walls of asci from which the spores have been shed appear in the middle. $\times 1,35^{\circ}$.

Fig. 42. Two young asci. $\times \mathrm{I}, 800$.

Fig. 43. A young ascus. The nuclei have not yet fused. $\times 2,700$.

Fig. 44. A young ascus, the nuclei fusing. $\times 2,700$.

Fig. 45. An ascus with young fusion nuclens. $\times 2,700$.

Fig. 46. Part of ascus, showing fusion nucleus in synapsis. $\times 2,700$.

Fig. 47. Fusion nucleus with what appear to be paired chromatin threads. $\times 2,700$.

Fig. 48. A similar, but somewhat later stage. $\quad \times 2,700$.

Figs. 49 and $49 a$. The same nucleus from two sections, showing the secondarily contracted chromatin. $\times 2,700$.

Fig. 50. The fusion nucleus with its four chromosomes standing in relation to the central body, but as yet no spindle has been formed. $\times 2,700$.

Fig. 51. The first spindle with central and mantle fibres and three of the four chromosomes. $\times 1,800$.

Fig. 52. The first spindle with two chromosomes, the right of which at least appears to have broken into two parts. $\times 2,700$.

Fig. 53. The first spindle, anaphase stage. $\times 2,700$.

\section{PLATE XL.}

Fig. 54. The first spindle, a later stage. Only the central fibres have persisted. There are indications of vacuolar cavities marking the beginnings of the daughter nuclei. $\quad \times 1,800$.

Fig. 55. One of the two daughter nuclei in division. $\times 2,700$. 
Fig. 56. A rather earlier stage in mitosis of the nuclei shown in Fig. 55. $\times 2,700$.

Fig. 57. The four-nucleate stage of the ascus. The sister nuclei are paired. $\times 1,800$.

Fig. 58. A prophase stage of the third mitosis. $\times 2,700$.

Fig. 59. A later period in the prophase. $\times 2,700$.

Fig. 60. Equatorial plate stage in third mitosis. $\times 1,800$.

Fig. 6r. A later period of same mitosis. $\times 2,700$.

Fig. 62. The daughter nuclei of the last mitosis about to form. Four of the eight shown-the two spindles have disappeared. Counting from the top the first and third are sisters. $\times \quad 1,800$.

Fig. 63. The young spores with nuclei still attached to one pole. Two of the four nonfunctional nuclei in upper part of ascus. $\times \mathrm{r}, 800$.

Fig. 64. Two young spores-a later stage than Fig. 63. The rays from the central body have floated in towards nucleus. $\times 1,800$.

Fig. 65. A later stage. The necks of nuclei have been retracted and nuclei are now spherical. $\times \mathbf{1}, 350$.

Fig. 66. A still later stage, showing the elongating spores and the still persistent non-functional nuclei. $\times 1,350$.

Fig. 67. A single mature spore. $\times 900$.

Figs. 68 and 69 . The resting primary nucleus of spore. $\times 2,700$.

Fig. 70. The primary spore nuclens in mitosis. $\times 2,700$. 
Annals of Botany,
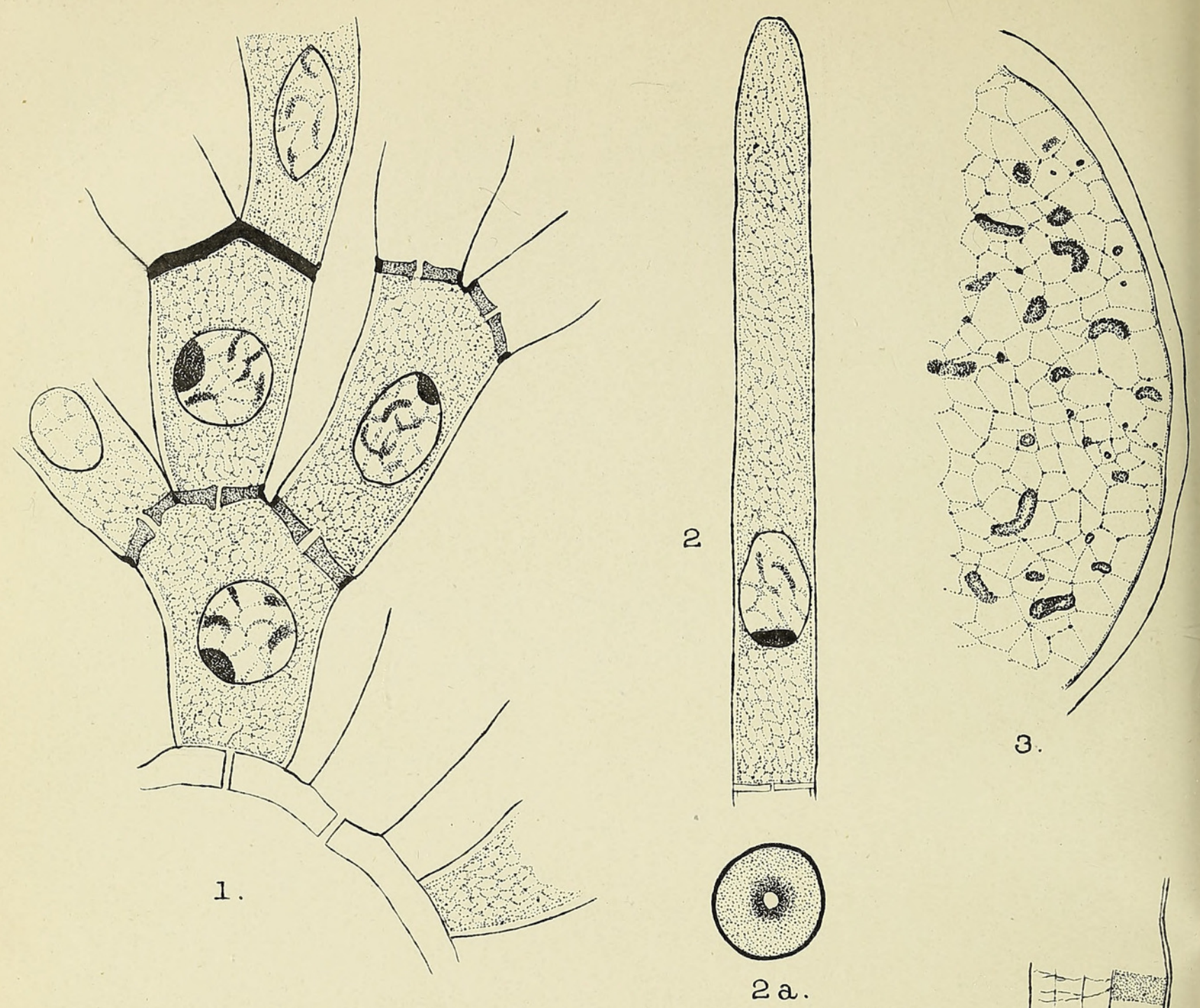

3.

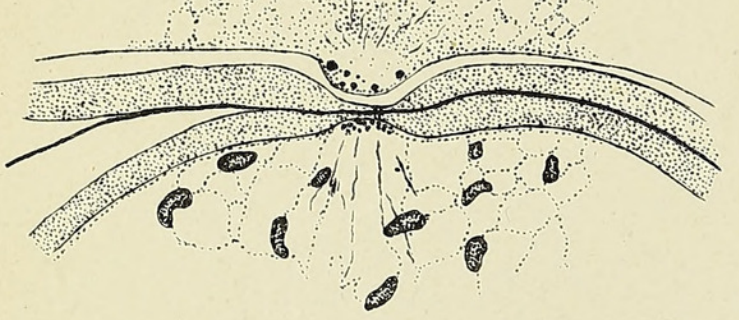

7.
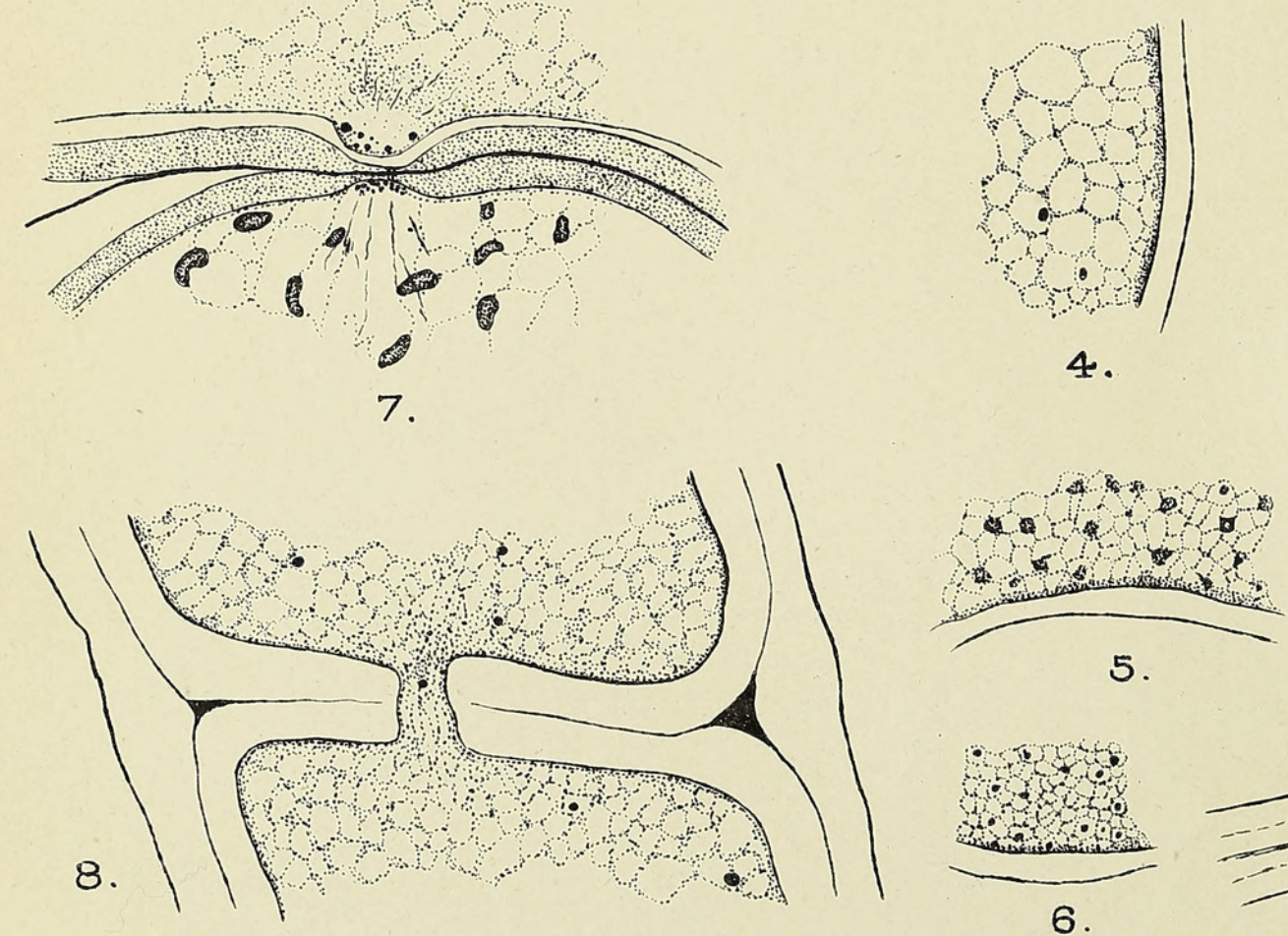

9.

FAULL - LABOULBENIA 
Vol.XXVI. Pl.XXXVII.

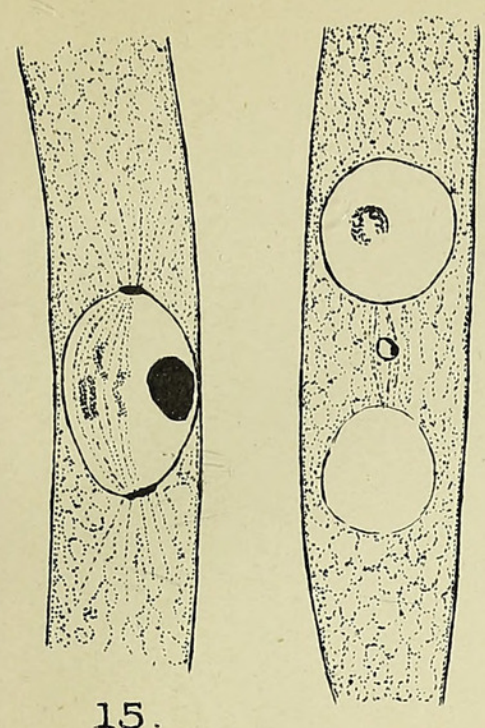

16.

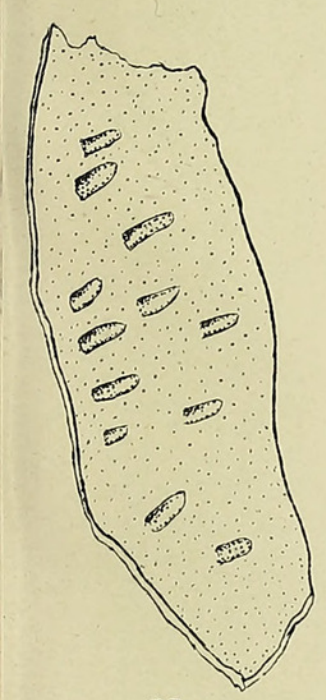

11.

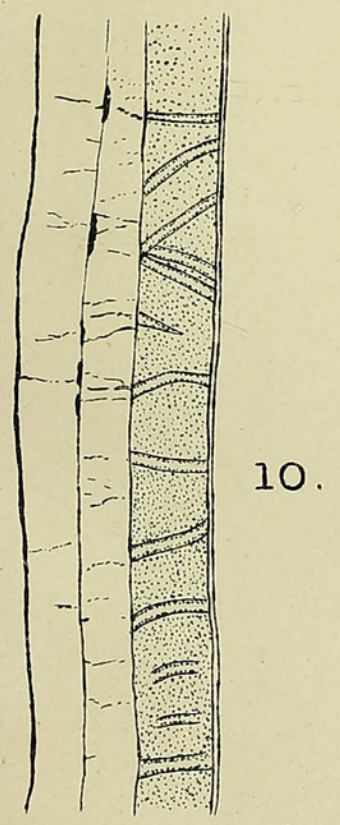

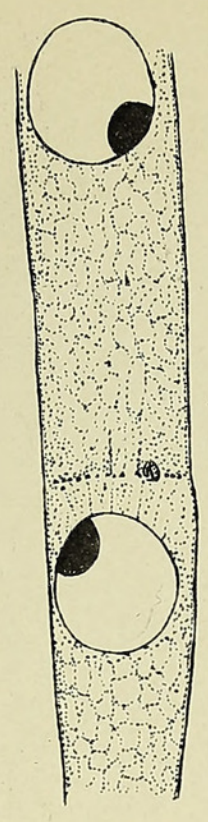

17.

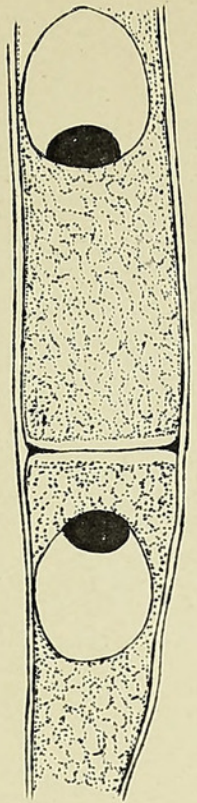

18.

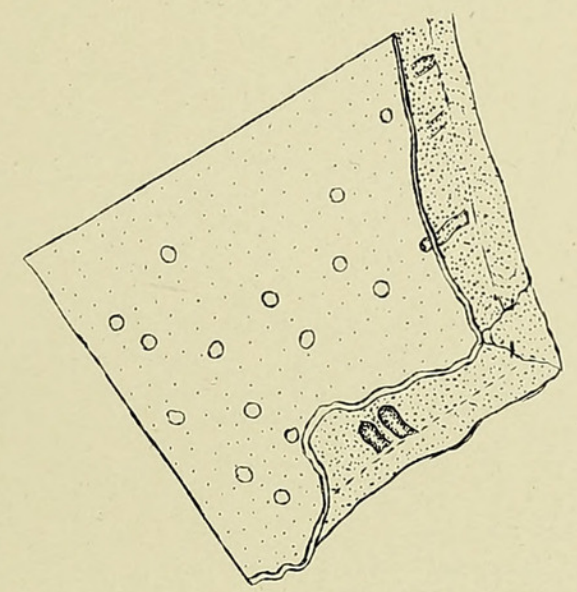

12.

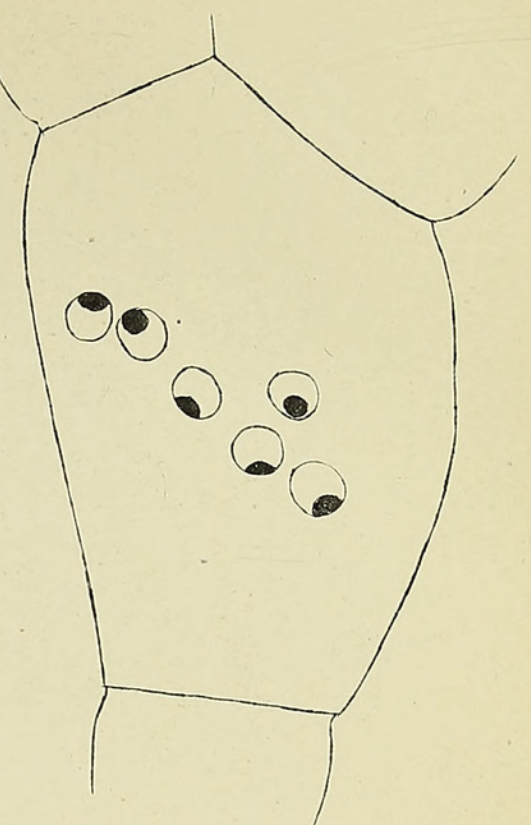

19.

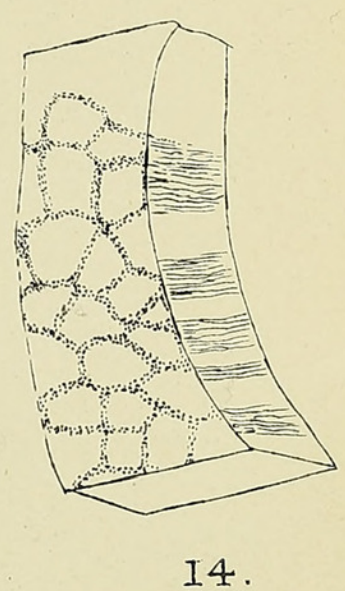

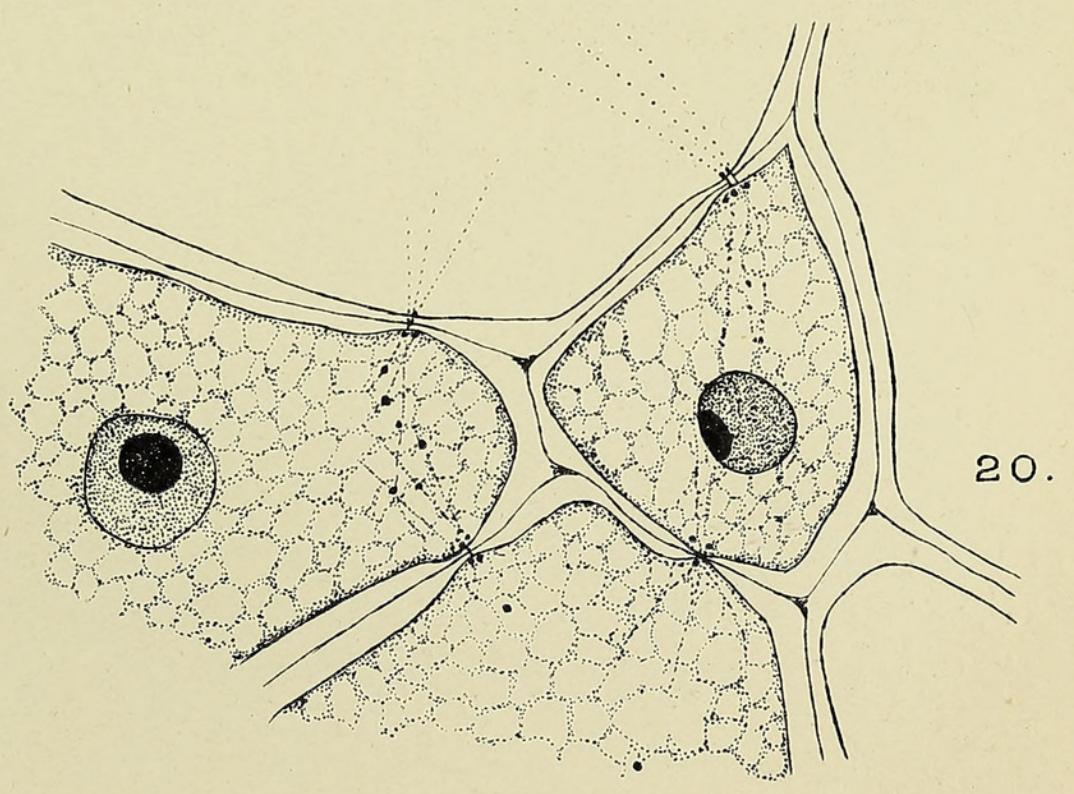

Huth, lith et imp. 
Annats of Botany,

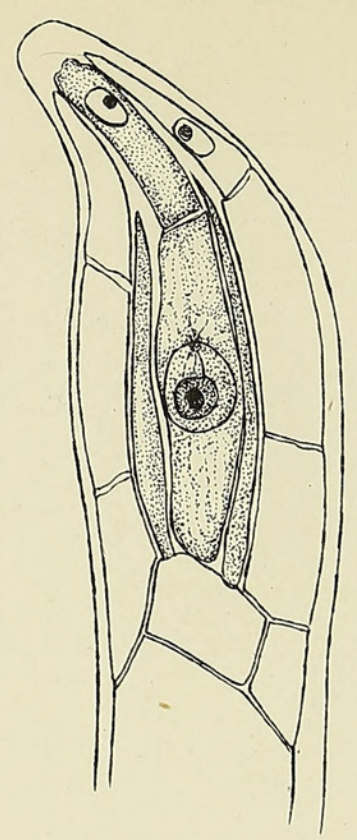

23.
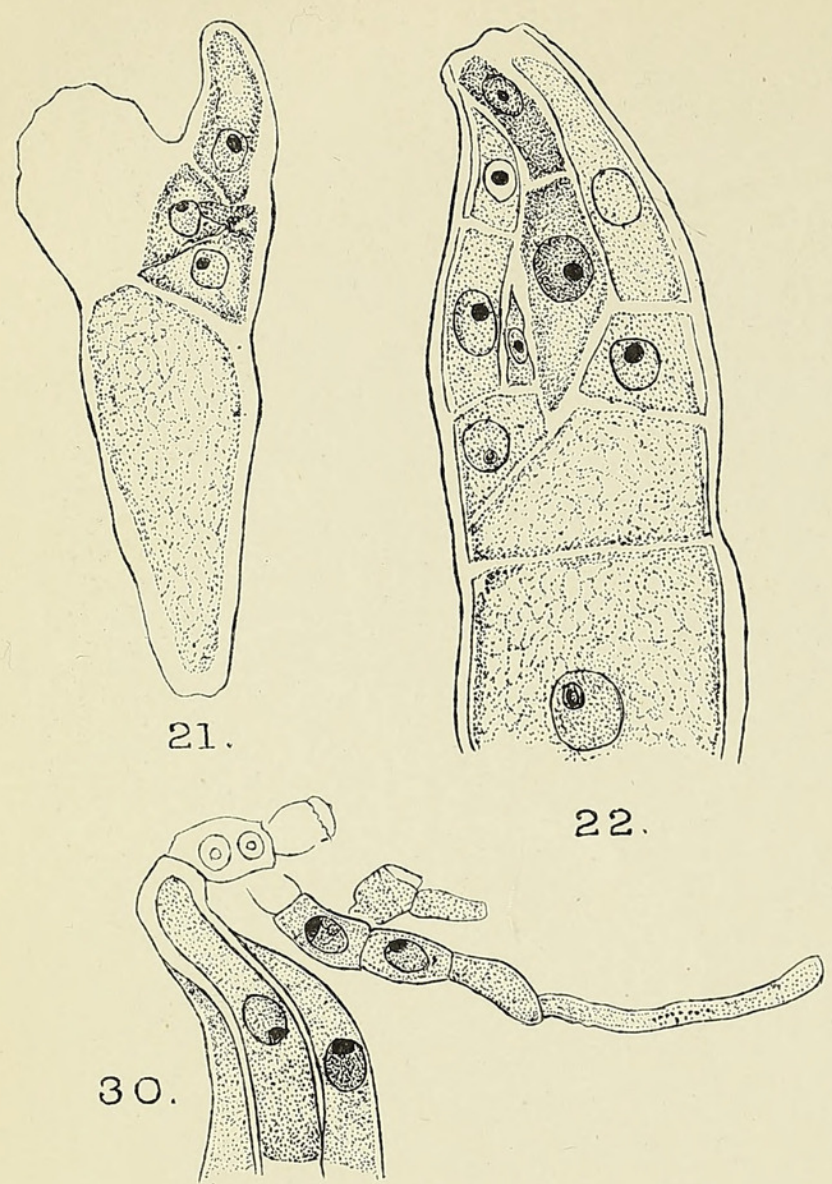

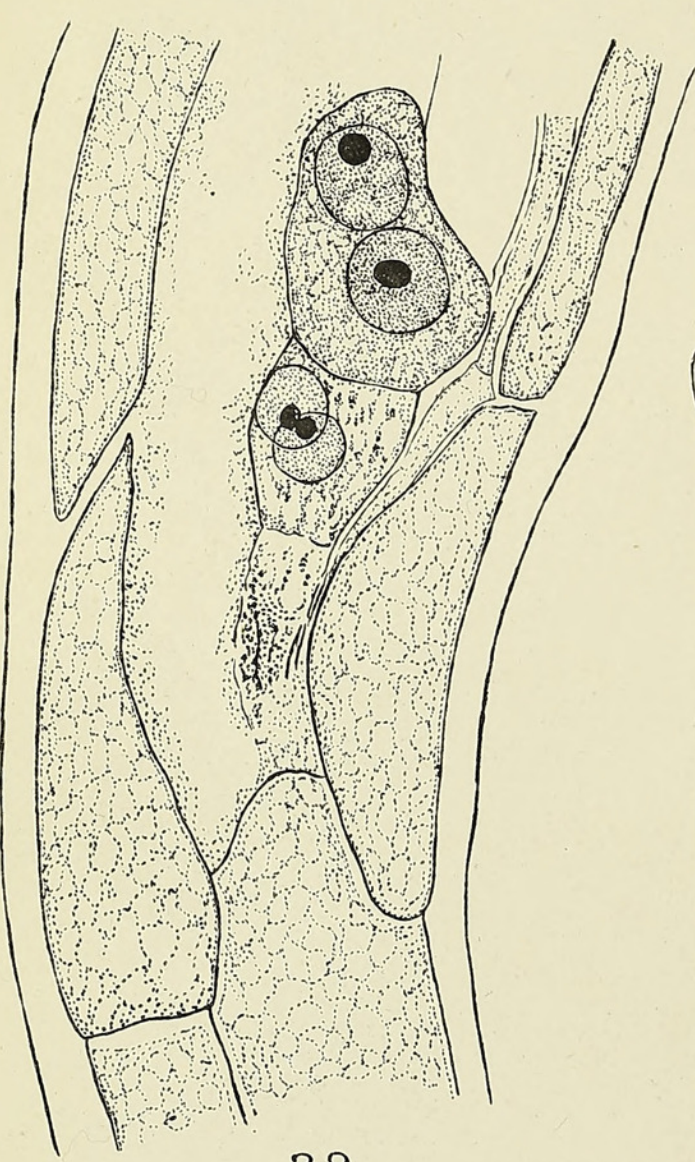

29.
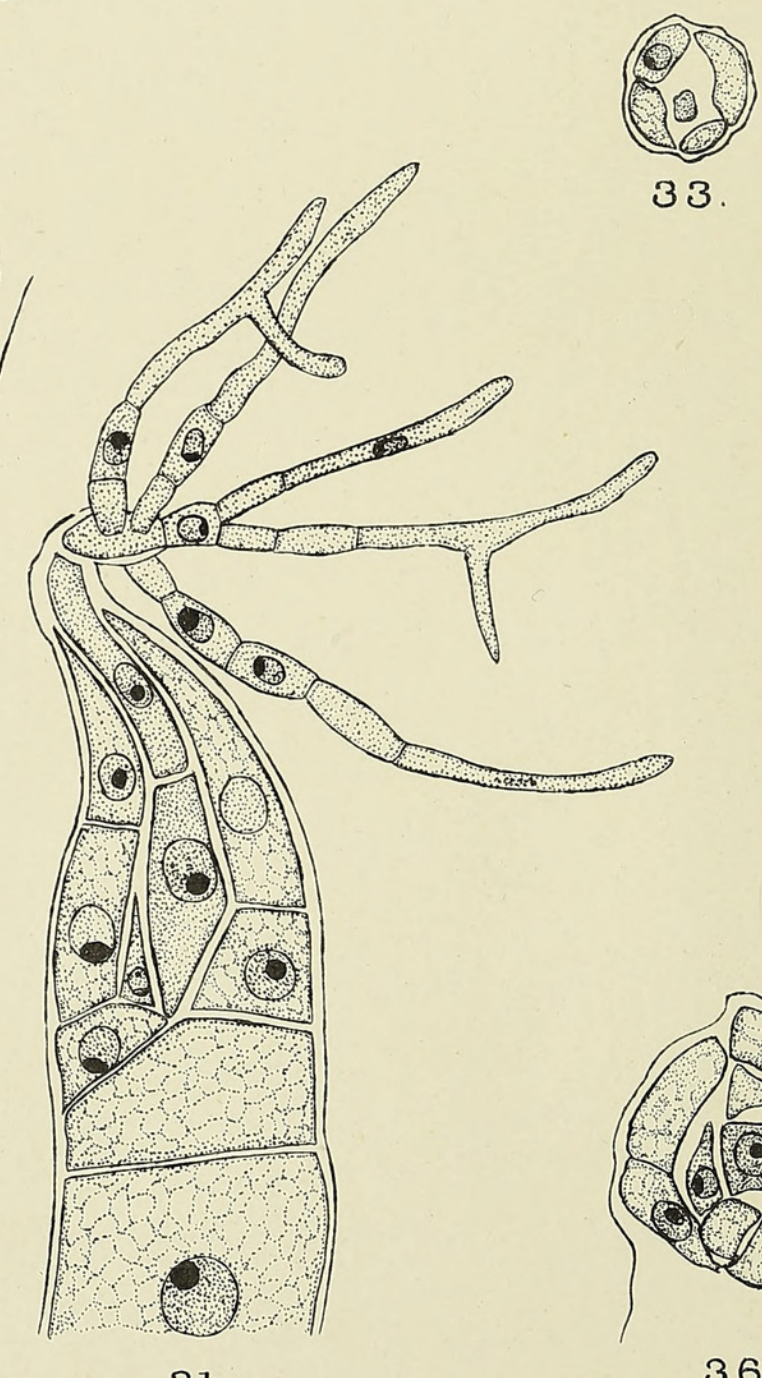

33.
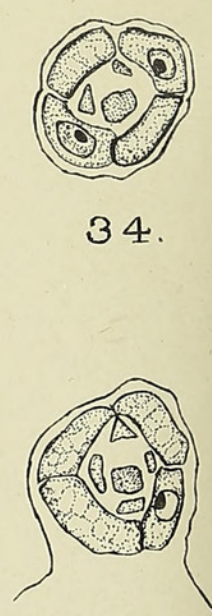

35.

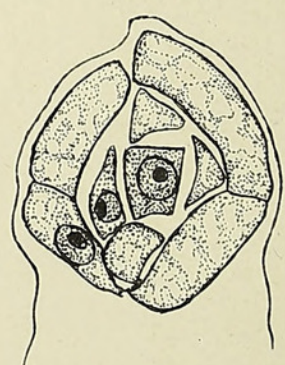

36. 
Vol.XXVI. Pl.XXXVIII.

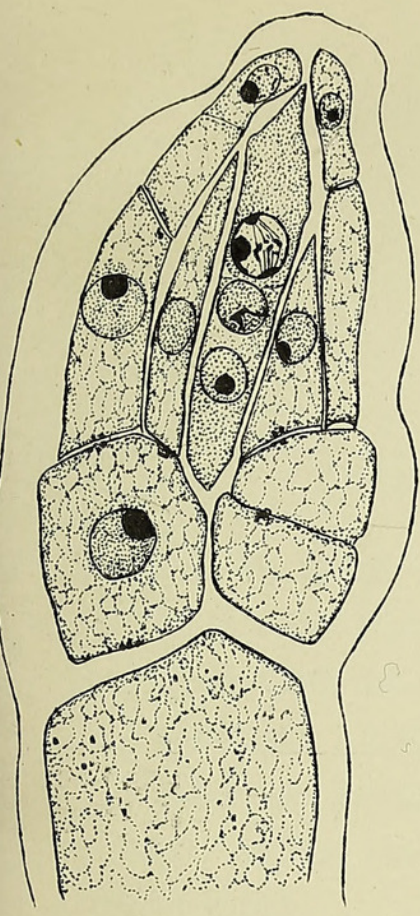

25.

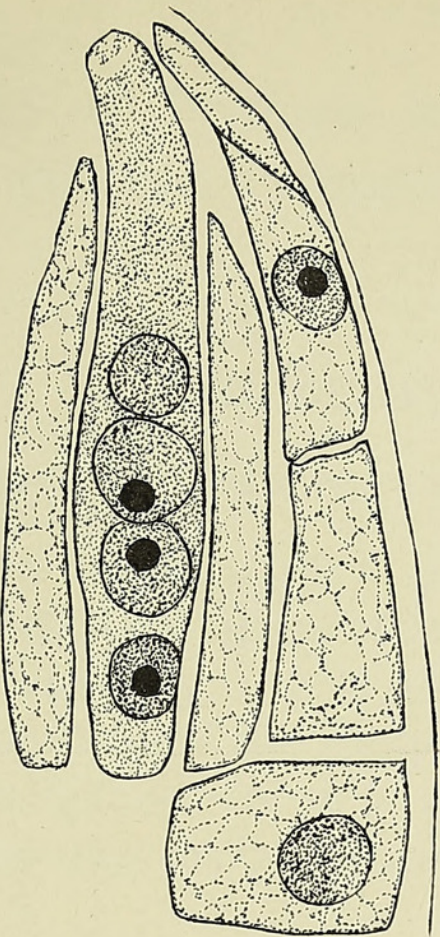

26.
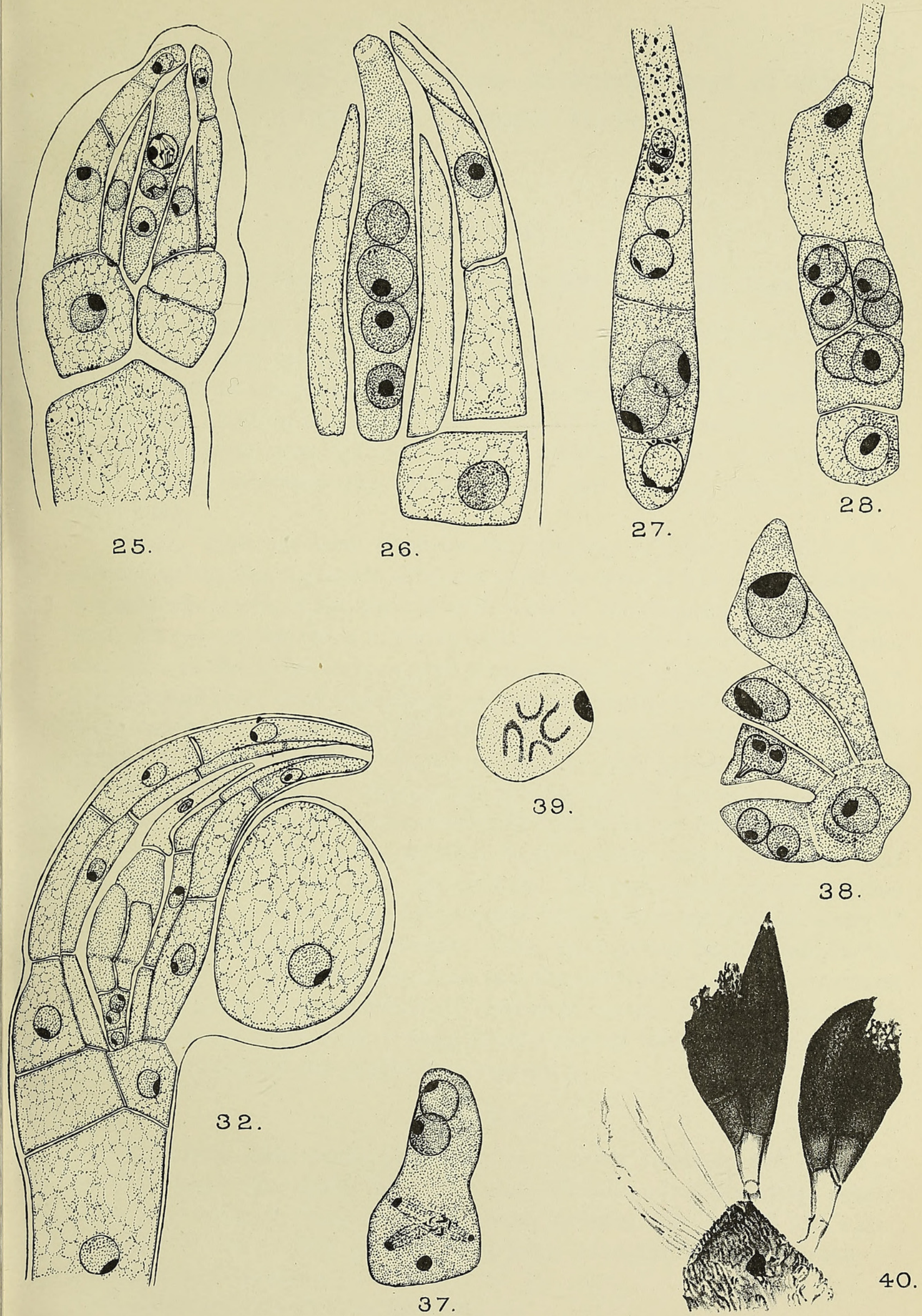

Huth, lith.et imp 
Annals of Botany.


FAULL- LABOULBENIA. 
Vol. XXVI. Pl.XXXIX.
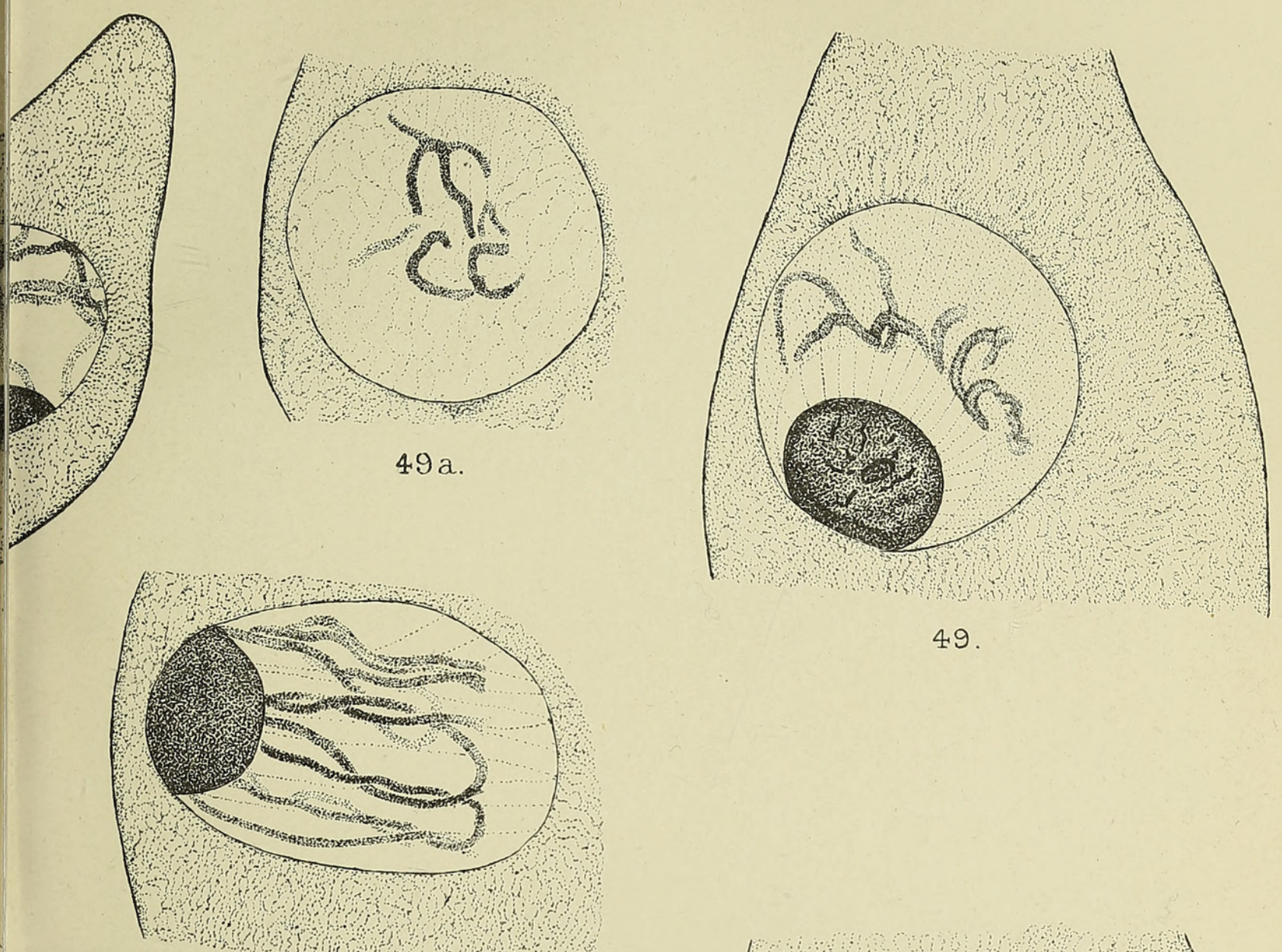

49

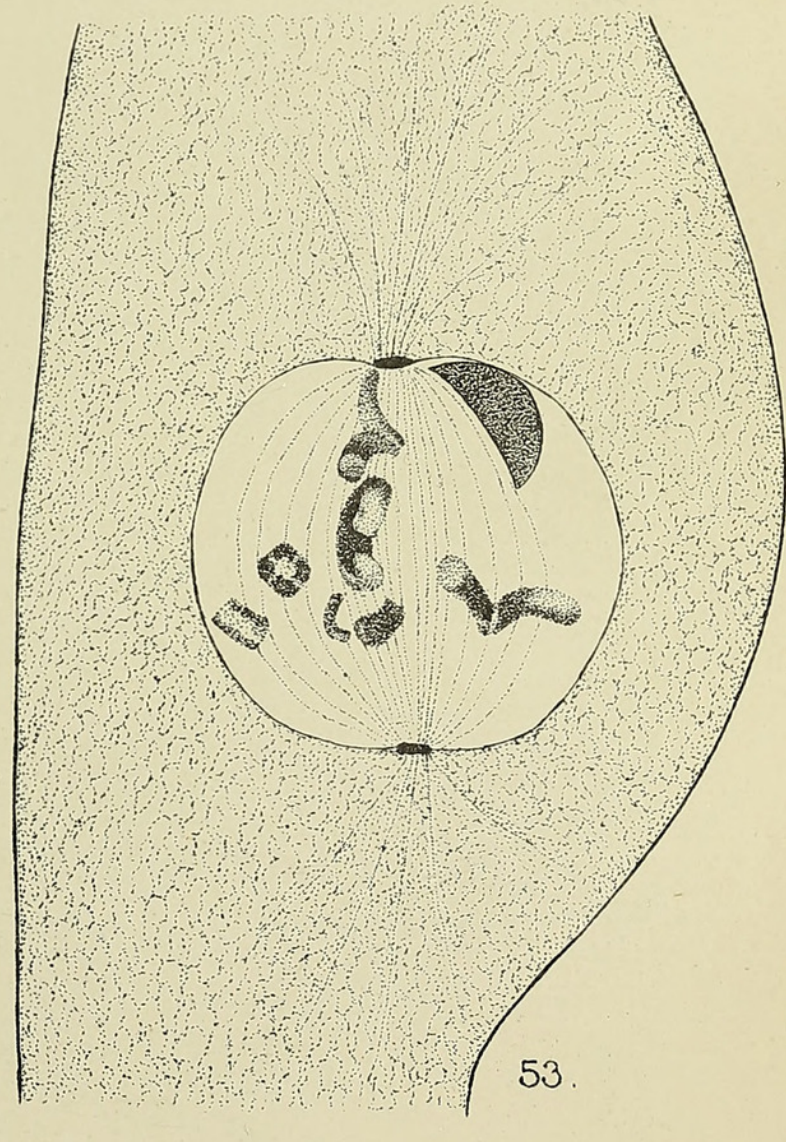

Froth, lith. et imp 

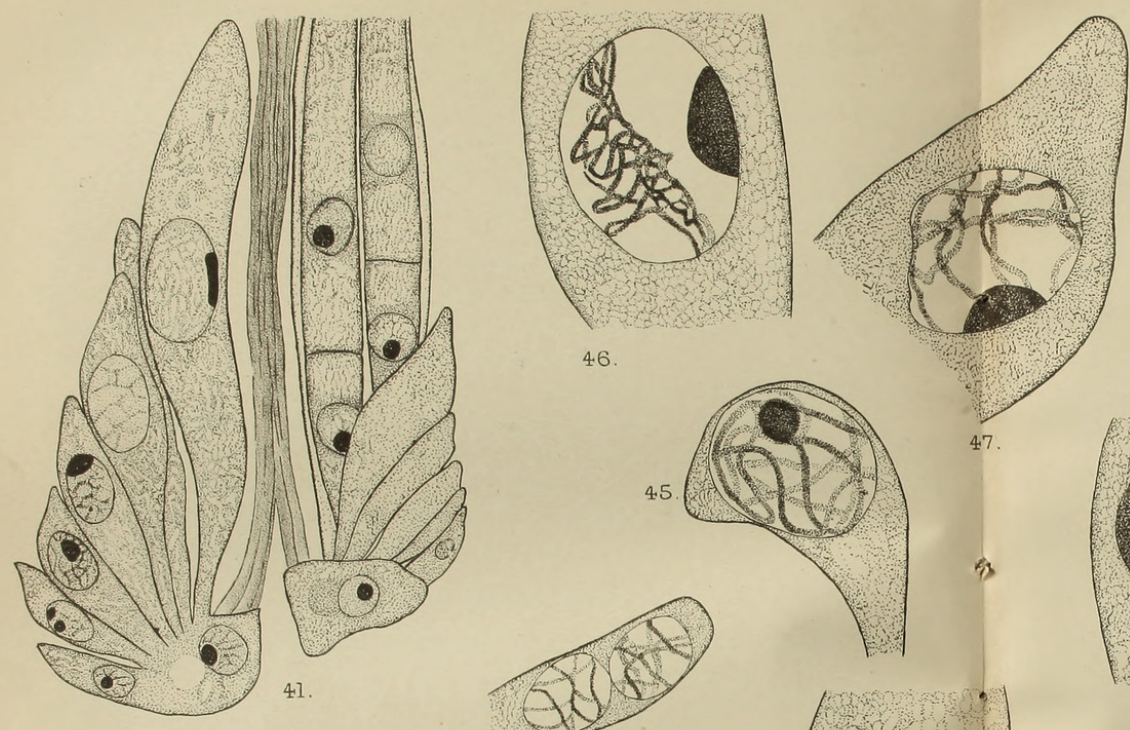

46.
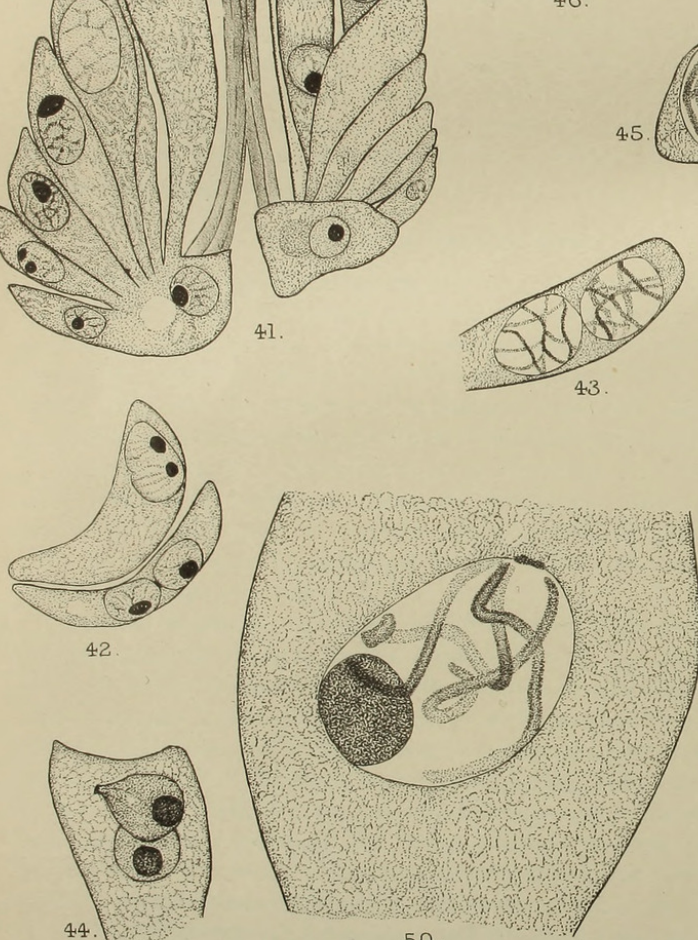

43

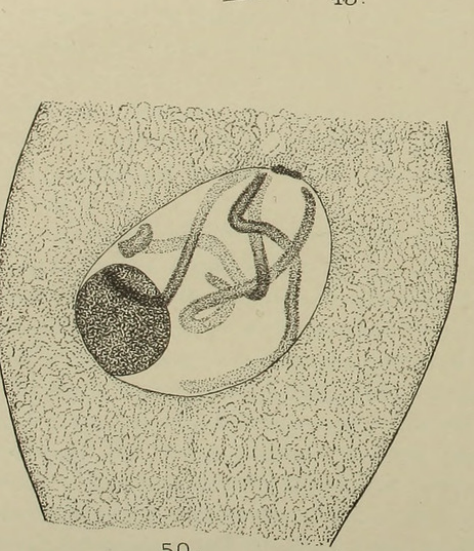

50
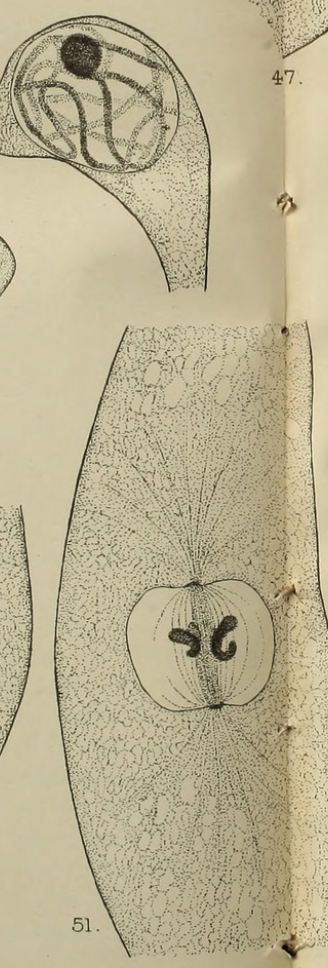

Futh, lith. et inp
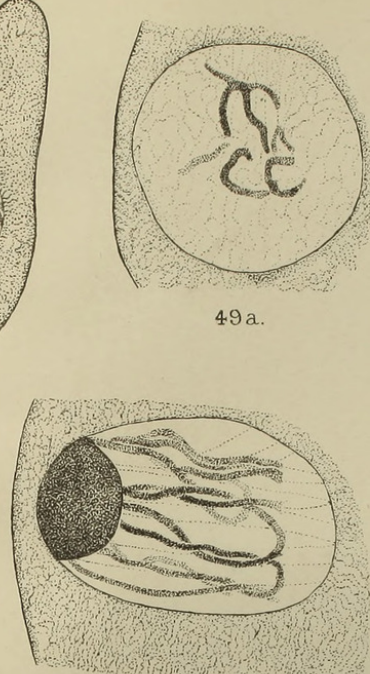

49 a.

48.
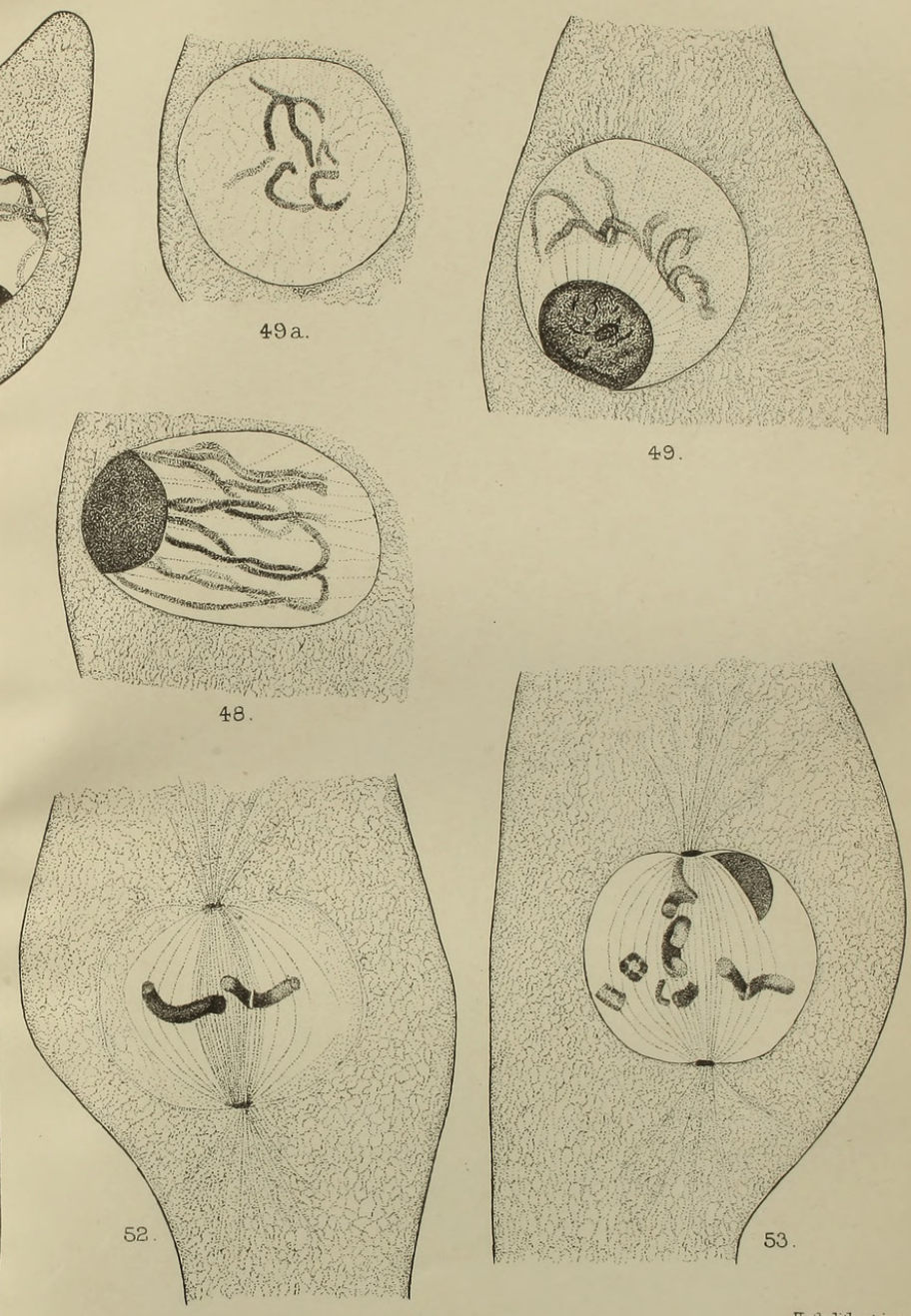
Annals of Botany.

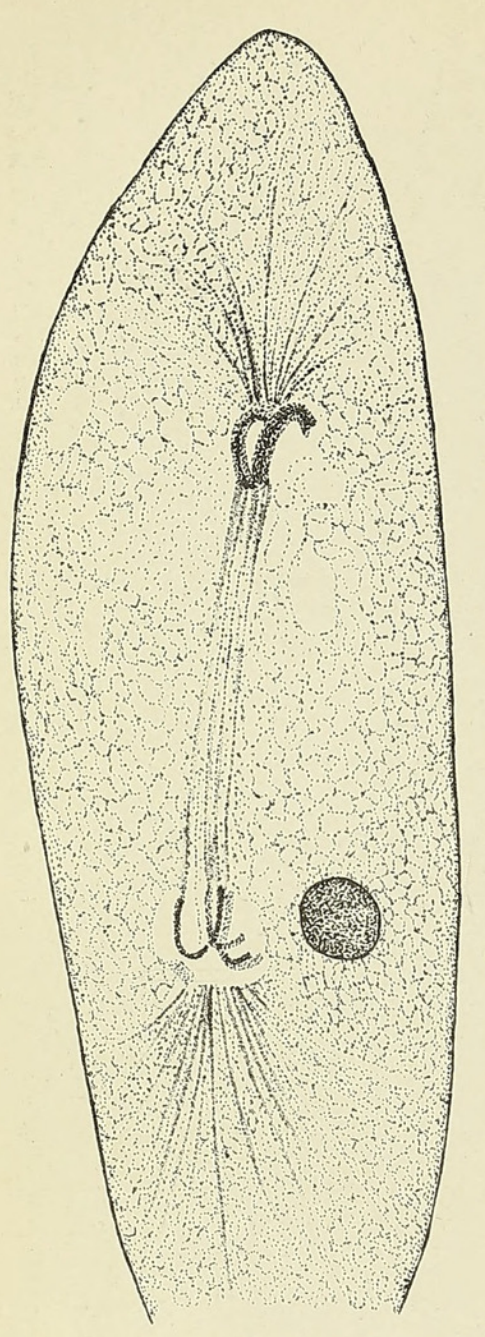

54.

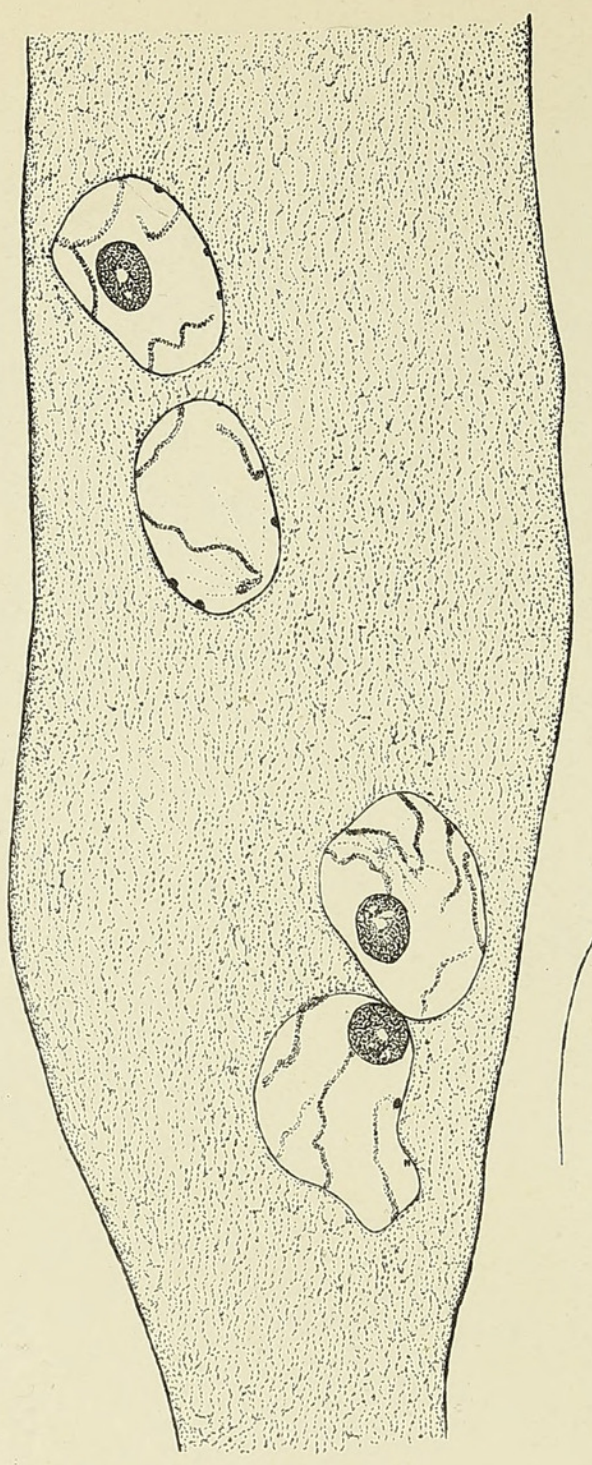

57.

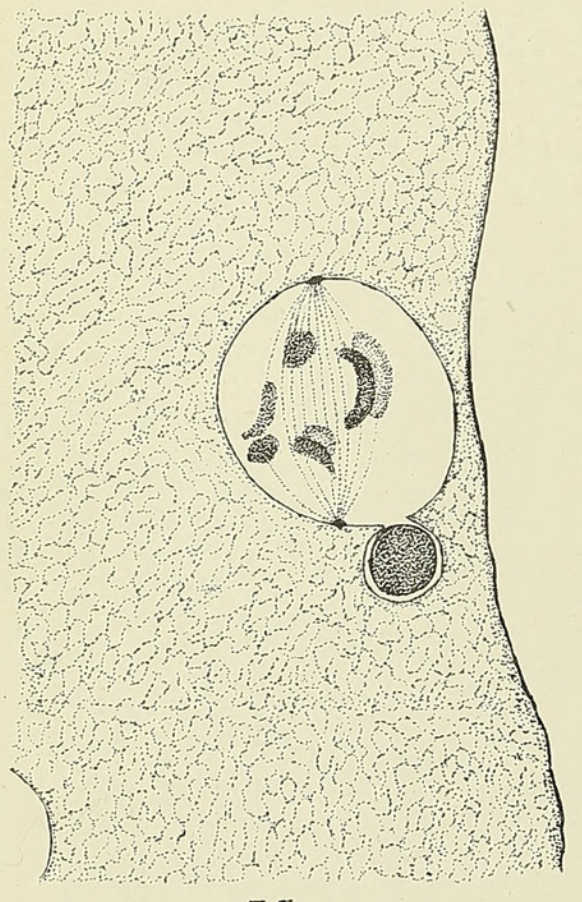

55

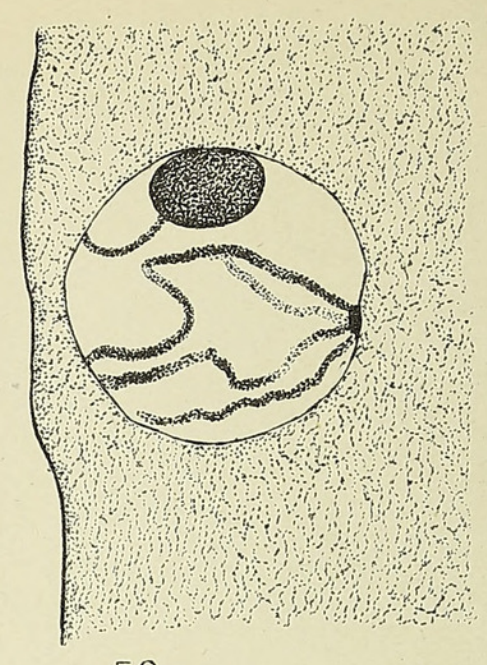

58.
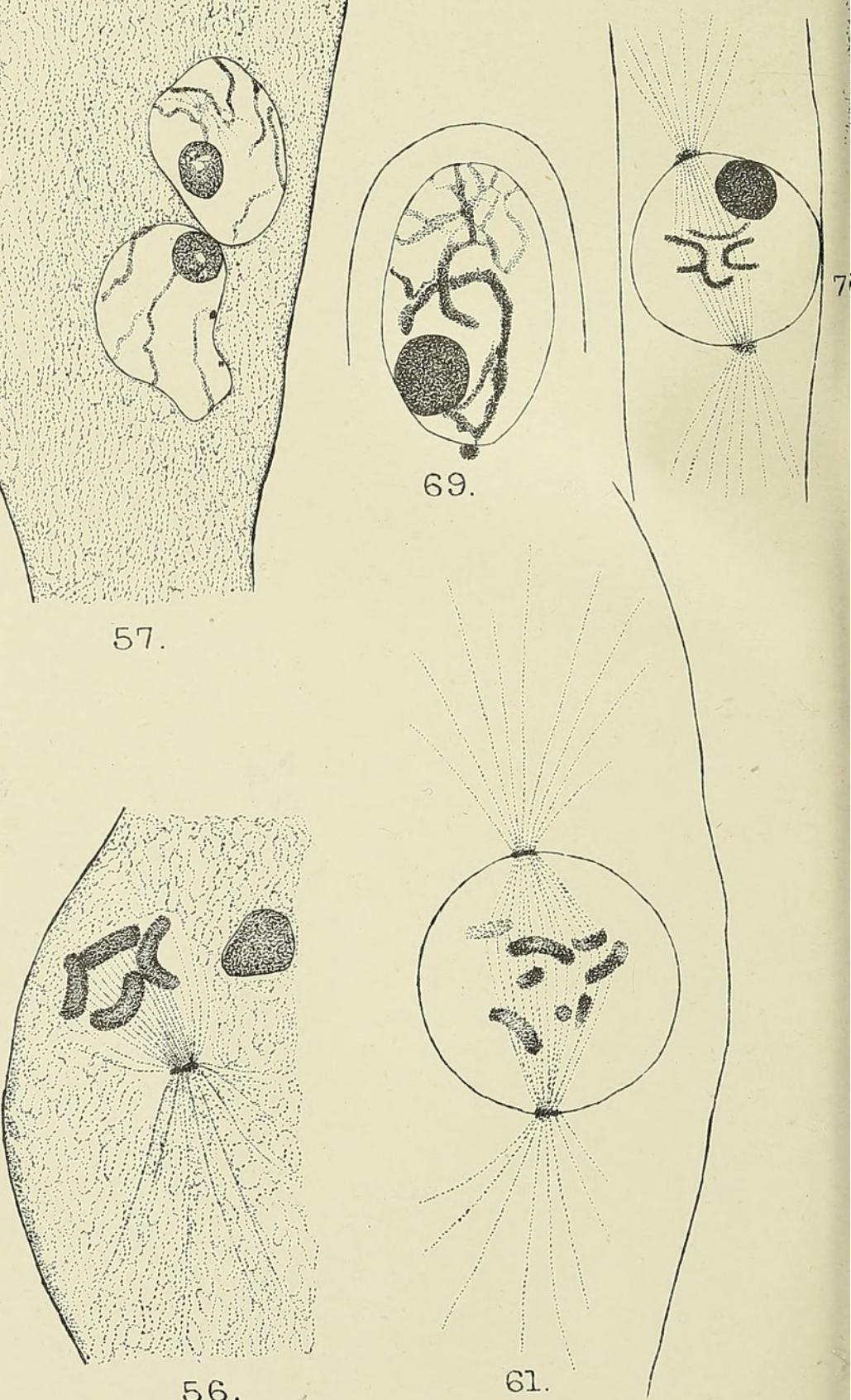

56.

FAULL - LABOULBENIA. 
Vol. XXVI. Pl.XL.

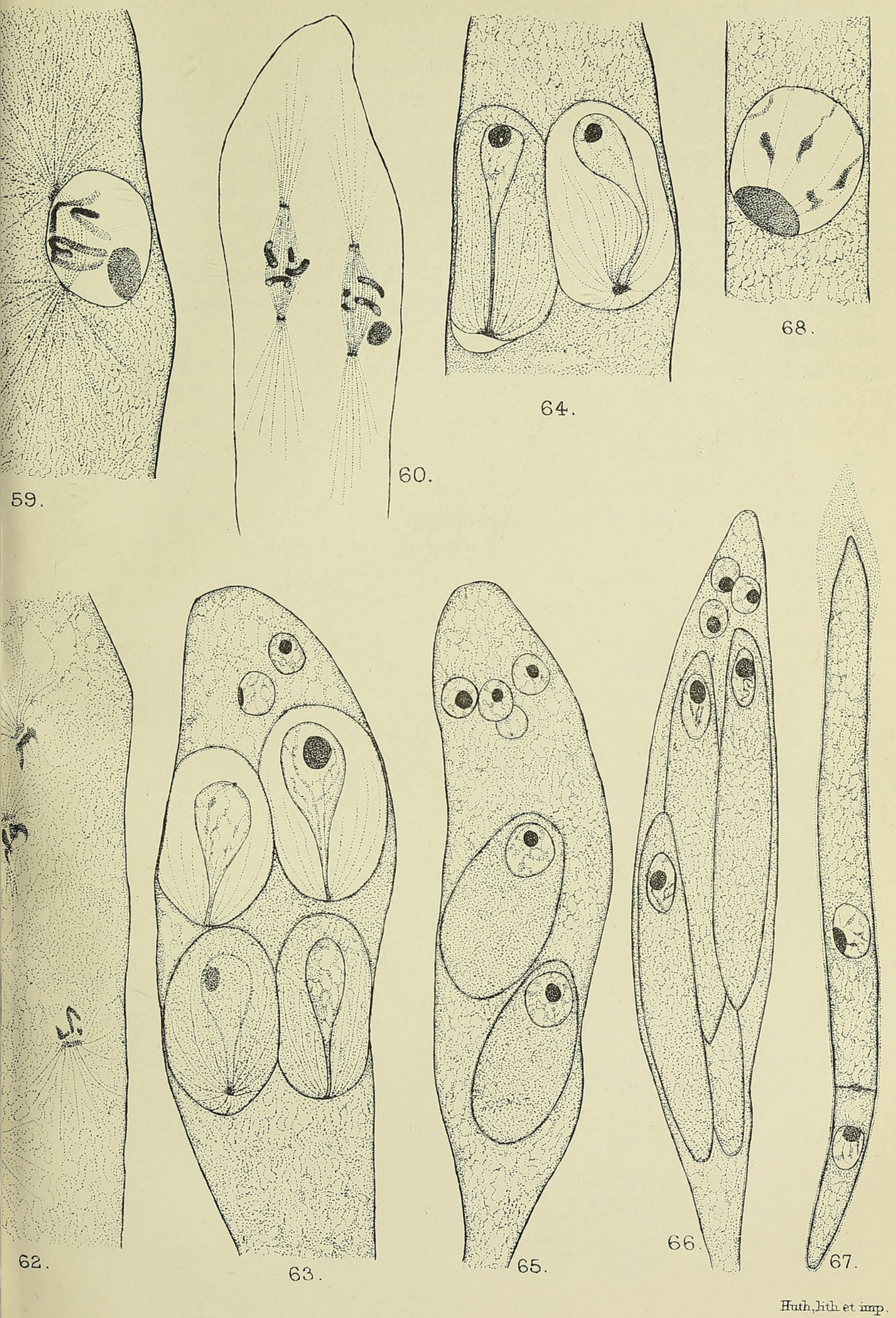


Annals of Botany.

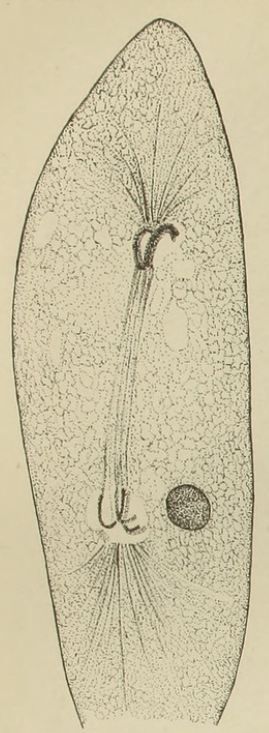

54.

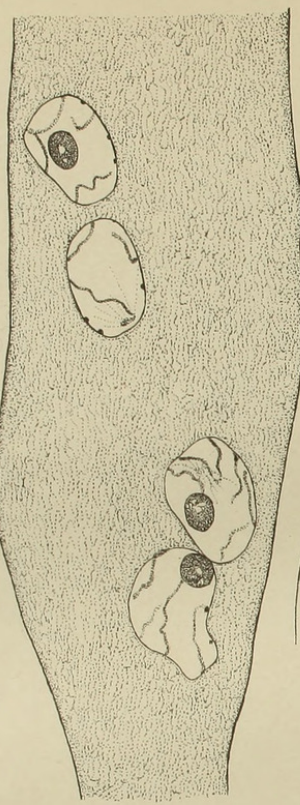

57.

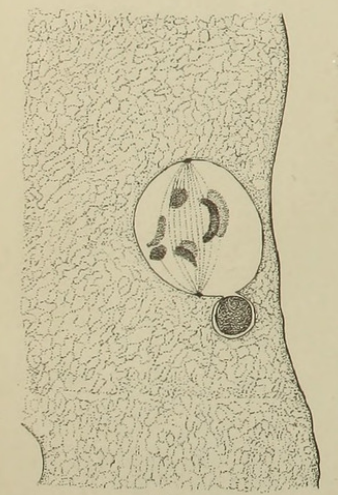

55.

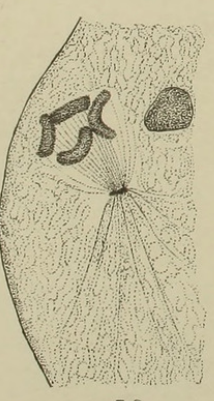

56.

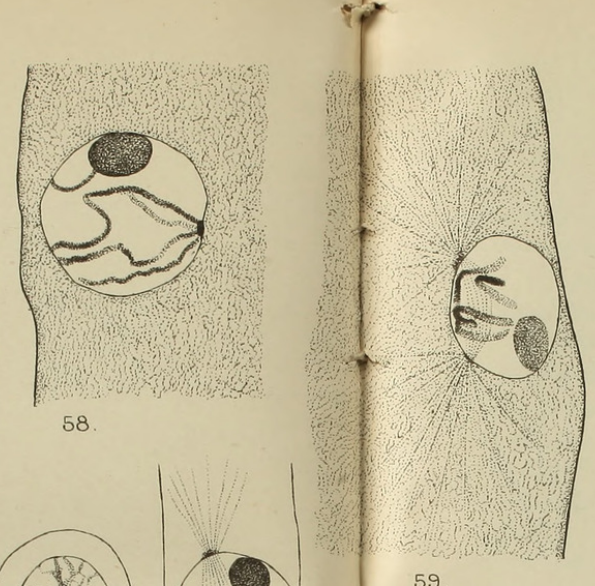

.

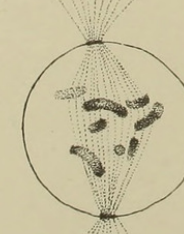

61.

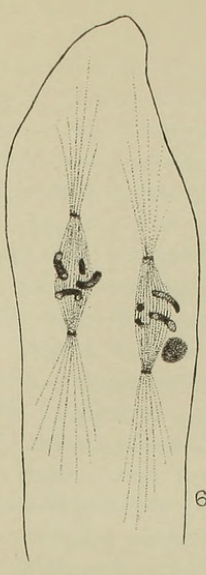

Vol. XXVI. PL. XL.

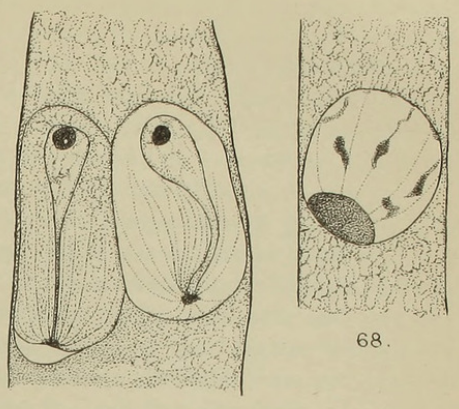

60.
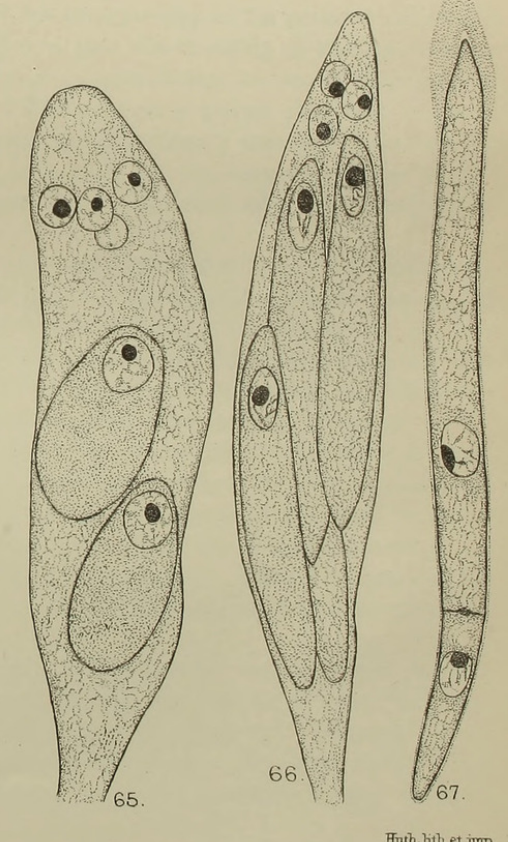


\section{$2 \mathrm{BHL}$ Biodiversity Heritage Library}

Faull, J. H. 1912. "The cytology of Laboulbenia chaetophora and L. gyrinidarum." Annals of botany 26, 325-355.

https://doi.org/10.1093/oxfordjournals.aob.a089394.

View This Item Online: https://www.biodiversitylibrary.org/item/236773

DOI: https://doi.org/10.1093/oxfordjournals.aob.a089394

Permalink: https://www.biodiversitylibrary.org/partpdf/319908

\section{Holding Institution}

Smithsonian Libraries

\section{Sponsored by}

Biodiversity Heritage Library

\section{Copyright \& Reuse}

Copyright Status: Not in copyright. The BHL knows of no copyright restrictions on this item.

This document was created from content at the Biodiversity Heritage Library, the world's largest open access digital library for biodiversity literature and archives. Visit BHL at https://www.biodiversitylibrary.org. 